\title{
Two new genera and five new species of Selachinematidae (Nematoda, Chromadorida) from the continental slope of New Zealand
}

\author{
Daniel LEDUC \\ National Institute of Water and Atmospheric Research (NIWA), Private Bag 14-901, Kilbirnie, \\ Wellington, New Zealand \\ E-mail: Daniel.Leduc@niwa.co.nz \\ urn:Isid:zoobank.org:author:9393949F-3426-4EE2-8BDE-DEFFACE3D9BC
}

\begin{abstract}
Two new genera and five new species of Selachinematidae are described from the New Zealand upper continental slope (350-1240 m depth). Synonchiella rotundicauda sp. nov. is characterised by cephalic setae 0.25 cbd long, mandibles each with two pairs of hooks and two wing-like projections laterally, eight cup-shaped pre-cloacal supplements and short rounded tail. Pseudocheironchus gen. nov. is similar to Cheironchus, but differs from the latter in having a cuticle without lateral differentiation, cephalic setae only slightly longer than the outer labial sensillae, and a posterior buccal cavity with three equal mandibles. Pseudocheironchus ingluviosus gen. et sp. nov. is characterised by mandibles with eight blunt teeth, multispiral amphideal fovea with five turns, and a short rounded tail. Males of this new species with 17-19 cup-shaped pre-cloacal supplements. Males of the genus Cobbionema are described for the first time; C. trigamma sp. nov. is characterised by four long cephalic setae and six smaller outer labial setae in one circle, six rhabdions surrounding the anterior buccal cavity, each with two pairs of pointed projections at their posterior extremities, posterior buccal cavity widening posteriorly, with three pairs of rhabdions fused posteriorly and widening anteriorly, males with two testes pointing anteriorly and with reflexed posterior testis, and no pre-cloacal supplements. Gammanema agglutinans sp. nov. is characterised by a short, stout body often covered in adhering mucus and detritus, cuticle with minute spines, leaf-shaped somatic setae with ducts, sexual dimorphism in the shape of the amphideal fovea (loop-shaped in males and spiral in females), posterior buccal cavity with three pairs of broad, column-shaped rhabdions fused anteriorly, intestine cells with orange-brown granules, and small tubular pre-cloacal supplements. Bendiella gen. nov. is most similar to Halichoanolaimus, but differs from the latter, and all other genera of the family Selachinematidae, in having a cuticle with lateral differentiation consisting of longitudinal rows of larger dots, and from all other genera of the Choniolaiminae in lacking pre-cloacal supplements. Bendiella thalassa gen. et sp. nov. is characterised by amphideal fovea with 5.25 turns, anterior buccal cavity with twelve rhabdions, each with a pair of pointed projections at posterior extremity, posterior buccal cavity with three Y-shaped pairs of slender rhabdions fused from two thirds of distance from anterior ends, and conico-cylindrical tail.
\end{abstract}

Key words. Selachinematinae, Choniolaiminae, marine predatory nematodes, bathyal, Southwest Pacific.

Leduc D. 2013. Two new genera and five new species of Selachinematidae (Nematoda, Chromadorida) from the continental slope of New Zealand. European Journal of Taxonomy 63: 1-32. http://dx.doi.org/10.5852/ejt.2013.63 


\section{Introduction}

The family Selachinematidae Cobb, 1915 is a group of predatory nematodes widespread in the world's oceans (e.g., Jensen 1987; Pereira et al. 2009). The taxonomy of the group was revised in detail by Gerlach (1964). A key to the genus Synonchiella Cobb, 1933 was provided by Fadeeva (1988), and, more recently, Tchesunov \& Okhlopkov (2006) reviewed and described some selachinematid specimens from the Northeast Atlantic and provided an emended diagnosis for the genus Cheironchus Cobb, 1917. Selachinematids are most often reported from relatively coarse sediments in shallow water environments (e.g., Warwick 1971; Okhlopkov 2002; Tchesunov \& Okhlopkov 2006). They also occur in deep-sea habitats, with eight species belonging to three genera recorded from water depths $>400 \mathrm{~m}$ worldwide (Miljutin et al. 2010).

Only two species of Selachinematidae are presently known from the New Zealand Exclusive Economic Zone, viz., Halichoanolaimus ovalis Ditlevsen, 1921 and H. robustus (Bastian, 1865) (Leduc \& Gwyther 2008). Here, two new genera and five new species of Selachinematidae are described from the continental slope of New Zealand (350-1240 m depth).

\section{Material and Methods}

Sediment samples were obtained from the Chatham Rise and Challenger Plateau, two major bathymetric features of the continental slope of New Zealand. Details of the study region and sampling sites are given in Leduc et al. (2012a, 2012b). Briefly, samples were collected along a transect at $178^{\circ} 30^{\prime} \mathrm{E}$ across the Chatham Rise (nine sites, 350-3100 m depth) in austral spring (September-October) 2001 during National Institute of Water and Atmospheric Research (NIWA) cruise TAN0116. Twenty-three additional sites between 240 and $1300 \mathrm{~m}$ depths on the Chatham Rise and Challenger Plateau were sampled in austral autumn-early winter (March-April and May-June) 2007 (NIWA cruises TAN0705 and TAN0707, respectively). Additional samples were obtained in February 2011 (NIWA cruise TAN1103) from a site near the middle of Chatham Rise crest at $350 \mathrm{~m}$ depth, and in November 2011 (NIWA cruise TAN1116) from a site on the northern flank of Chatham Rise at $470 \mathrm{~m}$ depth.

Sediment samples were collected using an Ocean Instruments MC-800A multicorer (core internal diameter $=9.5 \mathrm{~cm}$ ). Each sample consisted of one subcore of internal diameter $26 \mathrm{~mm}$ taken to a depth of $5 \mathrm{~cm}$. Samples were fixed in $10 \%$ formalin and stained with Rose Bengal. Samples were subsequently rinsed on a $1 \mathrm{~mm}$ sieve to remove large particles and on a $45 \mu \mathrm{m}$ sieve to retain nematodes. Nematodes were extracted from the remaining sediments by Ludox flotation and transferred to pure glycerol (Somerfield \& Warwick 1996). Species descriptions were made from glycerol mounts using differential interference contrast microscopy and drawings were made with the aid of a camera lucida. All measurements are in $\mu \mathrm{m}$, and all curved structures are measured along the arc. Type specimens are held in the NIWA Invertebrate Collection (NIC), Wellington. Abbreviations in the text are as follows:

$\begin{array}{lll}\mathrm{a} & = & \text { body length/maximum body diameter } \\ \mathrm{abd} & = & \text { anal body diameter } \\ \mathrm{b} & = & \text { body length/pharynx length } \\ \mathrm{c} & = & \text { body length/tail length } \\ \mathrm{cbd} & = & \text { corresponding body diameter } \\ \mathrm{L} & = & \text { body length } \\ \mathrm{n} & = & \text { number of specimens } \\ \% \mathrm{~V} & = & \text { vulva distance from anterior end of body } \times 100 / \text { total body length }\end{array}$




\section{Results}

Class Chromadorea Inglis, 1983

Subclass Chromadoria Pearse, 1942

Order Chromadorida Chitwood, 1933

Suborder Chromadorina Filipjev, 1929

Superfamily Chromadoroidea Filipjev, 1917

Family Selachinematidae Cobb, 1915

\section{Diagnosis}

(Modified from Decraemer \& Smol 2006.) Body usually stout. Cuticle punctated with or without lateral differentiation. Head sensillae may be jointed. Amphideal fovea usually multispiral, rarely loopshaped. Buccal cavity spacious, divided into two compartments, either reinforced by cuticularised rhabdions in both portions (Choniolaiminae), or with posterior rhabdions modified into protrusible mandibles (Selachinematinae). Pharynx with or without posterior bulb, anterior bulb sometimes present (Cheironchus and Pseudocheironchus gen. nov.). Males usually with two outstretched testes, either on same or different sides of the intestine; pre-cloacal supplements usually present, usually cup-shaped, sometimes setose, papilliform, rarely tubular. Female didelphic-amphidelphic with reflexed ovaries.

\section{Remarks}

The holophyly of the family Selachinematidae is based on the holapomorphy of a spacious buccal cavity without teeth or, if teeth are present, they are not homologous with teeth found in other Chromadorida (Lorenzen 1981).The family placement of Richtersia Steiner, 1916 and Desmotersia Neira \& Decraemer, 2009 remains uncertain and these genera are considered by some as intermediate between the Selachinematidae and Desmodoroidea (e.g., Pastor de Ward \& Lo Russo 2007; Neira \& Decraemer 2009). The genus Dignathonema Filipjev, 1918 was synonymised with Cheironchus Cobb, 1917 by Filipjev (1926). Trogolaimus Cobb, 1920 was classified in the subfamily Selachinematinae by Gerlach (1964), but, as Tchesunov \& Okhlopkov (2006) noted, this genus should be assigned to the Choniolaiminae based on the structure of the buccal cavity. The latter authors considered Trogolaimus to be a synonym of Gammanema Cobb, 1920. Nunema Cobb, 1933 and Pteronium Cobb, 1933 were considered doubtful by Hope \& Murphy (1972).

\section{Subfamily Selachinematinae Cobb, 1915}

\section{Diagnosis}

Anterior portion of buccal cavity reduced, posterior portion with three denticulate mandibles (modified rhabdions); dorsal mandible may be reduced.

\section{Valid genera}

Cheironchus Cobb, 1917

Demonema Cobb, 1894

Kosswigonema Gerlach, 1964

Synonchiella Cobb, 1933

Synonchium Cobb, 1920

\section{Type species}

Genus Synonchiella Cobb, 1933

Synonchiella truncata Cobb, 1933 


\title{
Diagnosis
}

Cuticle without lateral differentiation. Outer labial setae and cephalic setae usually in one circle. Buccal cavity with three equal mandibles made of two branches fused posteriorly; the two branches completely fused in some species (e.g., S. rotundicauda sp. nov.). Pharynx without posterior or anterior bulb. Cupshaped pre-cloacal supplements present.

\section{Remarks}

Synonchiella denticulata Cobb, 1933, S. ferox Cobb, 1933 and S. siphonolaimoides (Allgén, 1940) were considered doubtful by Gerlach (1964) due to incomplete descriptions. The latter author also transferred S. annulata Gerlach, 1952 and S. orcina Gerlach, 1952 to the genus Latronema.

\section{Valid species}

\author{
S. dilarae Fadeeva, 1988 \\ S. edax Aissa \& Vitiello, 1970 \\ S. forceps (Gerlach, 1957) \\ S. hopperi Ott, 1972 \\ S. japonica Fadeeva, 1988 \\ S. lutosa Gagarin \& Klerman, 2007 \\ S. major Murphy, 1965 \\ S. micramphis (Schuurmans-Stekhoven, 1950) \\ S. microspiculoides (Schuurmans-Stekhoven, 1946) \\ S. minor Murphy, 1965 \\ S. minuta Vitiello, 1970 \\ S. riemanni Warwick, 1970 \\ S. roscoffiensis De Coninck, 1965 \\ S. siphonolaimoides (Allgén, 1940) \\ S. spiculora Murphy, 1962 \\ S. truncata Cobb, 1933
}

\author{
Synonchiella rotundicauda sp. nov. \\ Figs 1-3, Table 1 \\ urn:1sid:zoobank.org:act:2145BDA7-84F7-4DF4-A401-7B706F0C0088
}

\section{Diagnosis}

Synonchiella rotundicauda sp. nov. is characterised by cephalic setae 0.25 cbd long, mandibles each with two pairs of hooks and two wing-like projections laterally, multispiral amphideal fovea with 3.5 turns, eight cup-shaped pre-cloacal supplements, and short tail (2.2. abd) with rounded extremity.

\section{Etymology}

The species name is derived from the Latin rotundus (= round, circular) and cauda (= tail), referring to the unusual rounded shape of the tail.

\section{Material examined}

\section{Holotype}

NEW ZEALAND: ${ }^{\AA}$, NIWA 88354, 17 Apr. 2007, NIWA cruise TAN0705, station 172, eastern Chatham Rise crest, $43.5162^{\circ} \mathrm{S}, 178.6167^{\circ} \mathrm{W}, 422 \mathrm{~m}$, fine sand (53.5\%), silt/clay (23.5\%), very fine sand (18.9\%).

\section{Paratype}

NEW ZEALAND: 1 , , NIWA 88355, 15 Nov. 2011, NIWA cruise TAN1116, station 107, northern flank of Chatham Rise, $42.8625^{\circ} \mathrm{S}, 177.9253^{\circ} \mathrm{E}, 467 \mathrm{~m}$. 

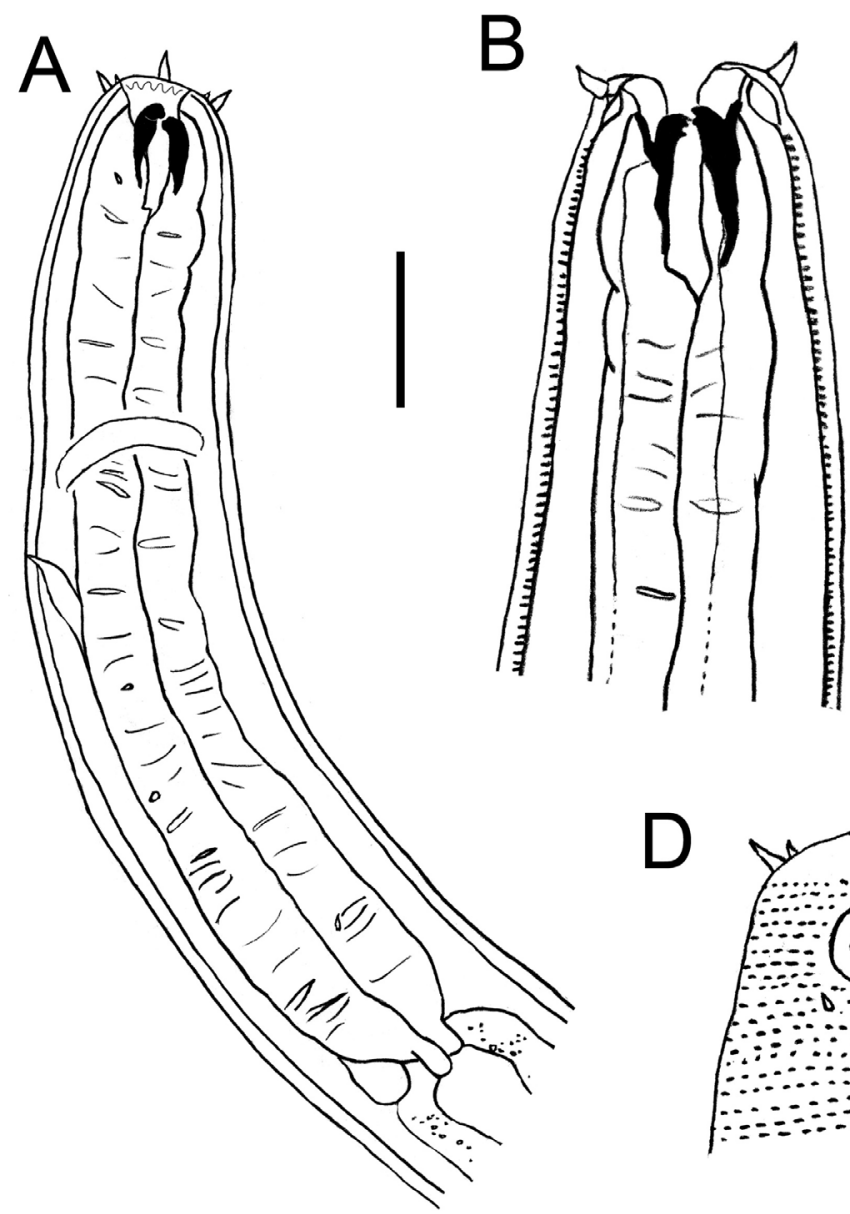

\section{$\mathrm{F}$}
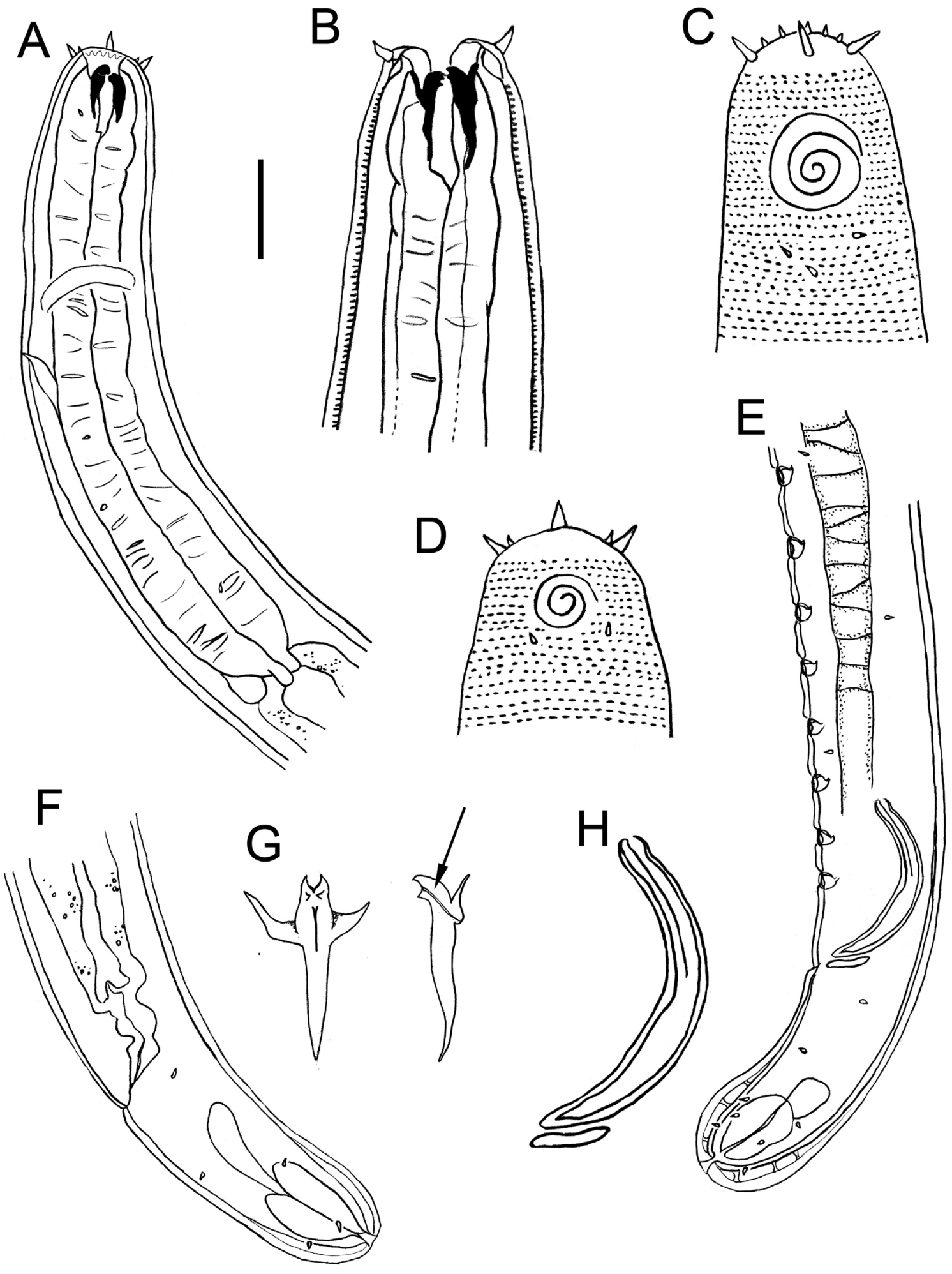

Fig. 1. Synonchiella rotundicauda sp. nov. A. Anterior body region of female. B. Male head. C. Surface view of male head. D. Surface view of female head. E. Male posterior body region. F. Female posterior body region. G. Mandibles, en face (left) and lateral (right) views. H. Spicule and gubernaculum. Arrow shows position of duct connecting anterior end of marginal tube and buccal cavity. Scale bar: A, E-F = $25 \mu \mathrm{m} ; \mathrm{B}-\mathrm{D}=15 \mu \mathrm{m} ; \mathrm{G}=8 \mu \mathrm{m} ; \mathrm{H}=13 \mu \mathrm{m}$. 


\section{Description}

\section{Male}

Body cylindrical, tapering slightly towards anterior extremity. Cuticle $\sim 2.0 \mu \mathrm{m}$ thick throughout body, thicker in tail region, $4 \mu \mathrm{m}$, with transverse rows of punctations, without lateral differentiation. Somatic setae short and sparse, in four sublateral rows. Head blunt, rounded, not set off. Six conical inner labial papillae, $\sim 1.5 \mu \mathrm{m}$ long; six longer outer labial setae, $4 \mu \mathrm{m}$ long, and four cephalic setae, $\sim 1 \mu \mathrm{m}$ long, situated close to or slightly anteriorly to outer labial setae (Fig. 1C). Amphideal fovea cuticularised, multispiral, 3.5 turns. Anterior portion of buccal cavity short and narrow, with inconspicuous rhabdions at anterior extremity. Posterior buccal cavity with three equal mandibles, $15 \mu \mathrm{m}$ long, with one mandible situated dorsally and two sub-ventrally; each mandible with two pairs of hooks at anterior extremity and two larger wing-like projections emerging laterally and pointing anteriorly; mandible also with small duct apparently connecting anterior extremity of marginal tubes and opening into buccal cavity near anterior end of mandible (Fig. 1G). Posterior buccal cavity surrounded by slightly swollen pharyngeal

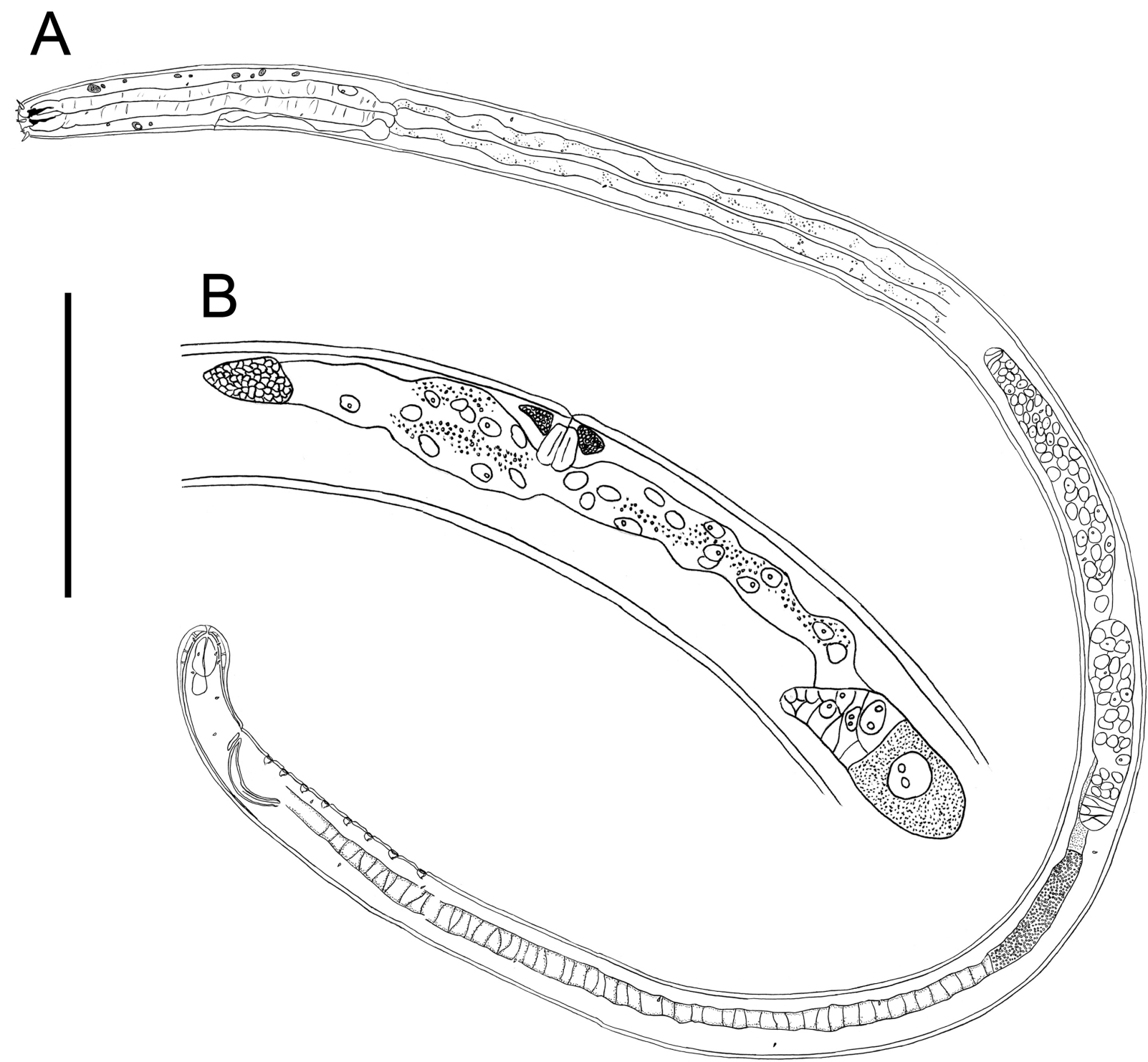

Fig. 2. Synonchiella rotundicauda sp. nov. A. Entire male. B. Female reproductive system. Scale bar: $\mathrm{A}=150 \mu \mathrm{m} ; \mathrm{B}=75 \mu \mathrm{m}$. 
tissue, pharynx widening posteriorly, not forming true bulb. Several light refractive, golden-brown corpuscules present in pharyngeal region (also present in tail; Fig. 3A, B). Nerve ring at $45 \%$ of pharynx length from anterior end. Secretory-excretory (S-E) system present, cellular body of ventral gland small, situated immediatly posterior to pharynx, pore situated $\sim 0.5 \mathrm{cbd}$ posterior to nerve ring.
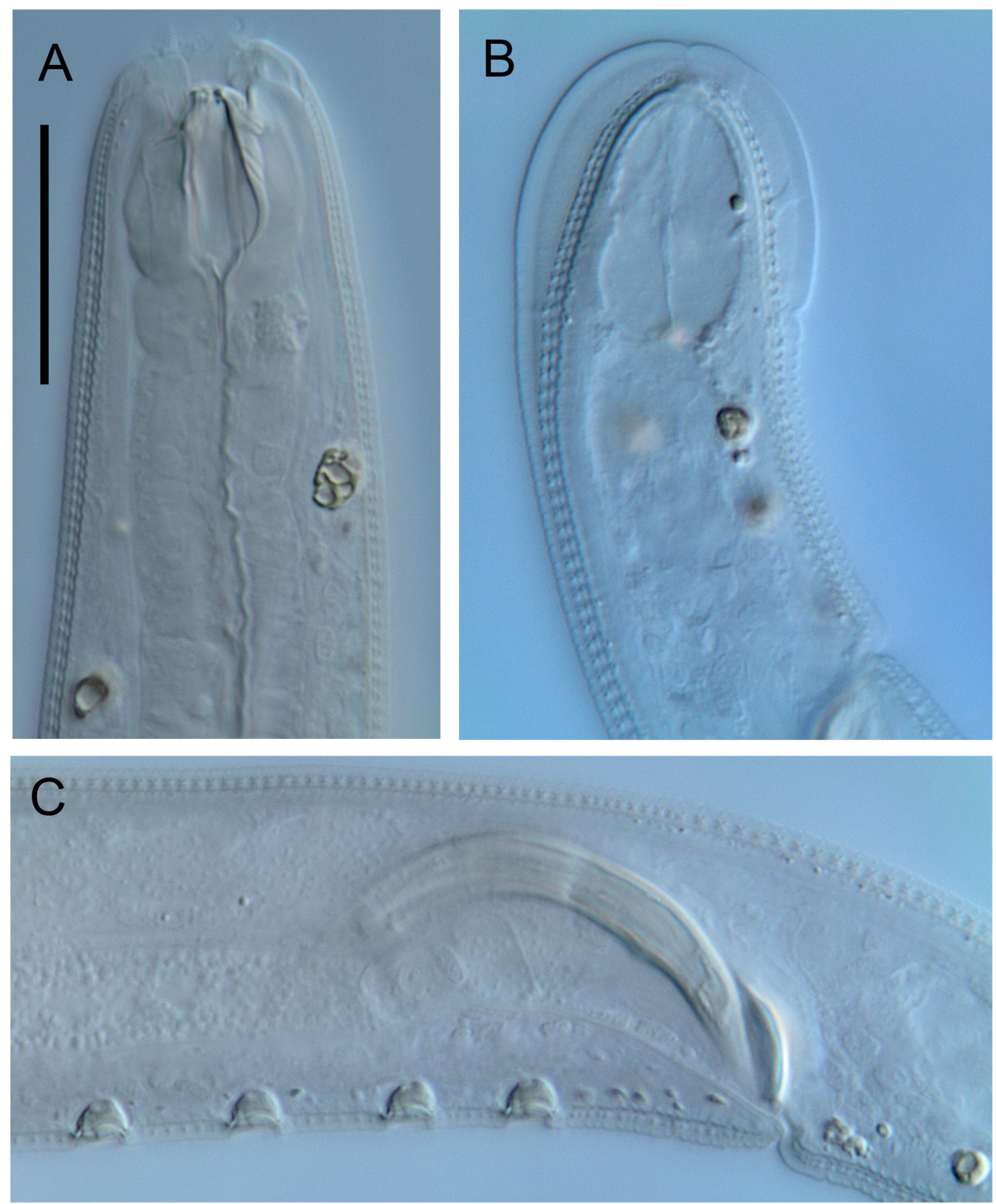

Fig. 3. Synonchiella rotundicauda sp. nov. Light micrographs. A. Anterior body region of male showing buccal cavity. B. Tail of male. C. Spicular apparatus. Scale bar $=25 \mu \mathrm{m}$. 


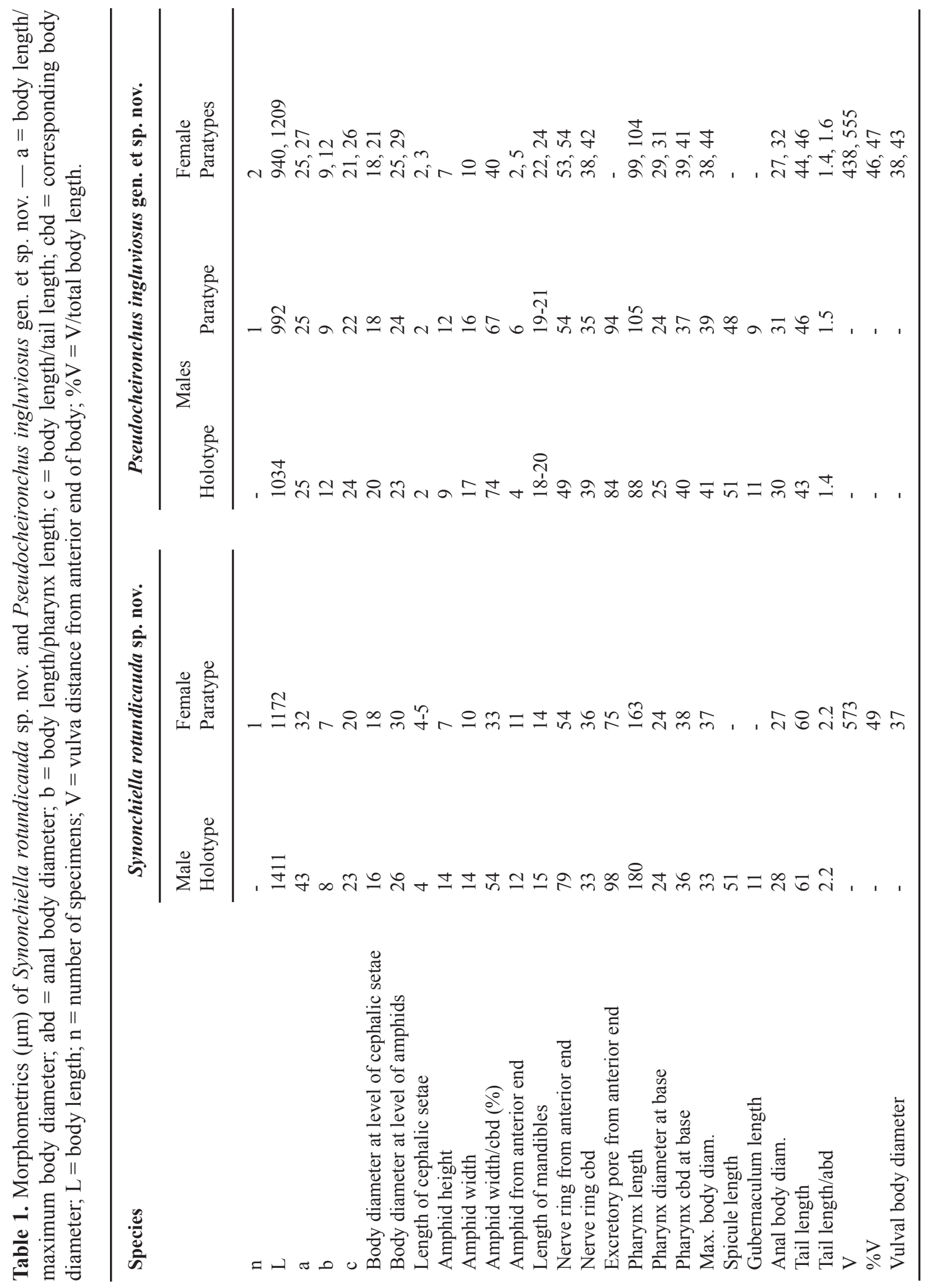


Reproductive system diorchic with outsretched testes. Both anterior and posterior testes on right of intestine. Oval-shaped, nucleated sperm cells, $\sim 6 \times 7 \mu \mathrm{m}$. Spicules paired, strongly curved, 1.8 abd long, widest in middle portion and tapering distally; thin cuticular projection extending from proximal end over almost half of spicule length. Gubernaculum small, plate-like, without lateral pieces, parallel to distal end of spicules. Mid-ventral row of eight cup-shaped pre-cloacal supplements, $\sim 4 \mu \mathrm{m}$ wide and $4 \mu \mathrm{m}$ deep, situated 6-8 $\mu \mathrm{m}$ apart; distance between supplements increasing slightly anteriorly. Pre-cloacal supplements thickly cuticularised with nerve entering anterior side of cup. No pre-or postcloacal setae or papillae observed. Tail short, with rounded posterior extremity, posterior half with few short setae and ducts, some of which are not connected to setae; terminal setae not observed. Three caudal glands and small spinneret present.

\section{Female}

Similar to males, but with smaller amphideal fovea, 2.5 turns. Reproductive system with posterior ovary reflexed, on right of intestine; anterior ovary poorly developed (Fig. 2B). Vulva located at mid-body. Vaginal glands present, pars proximalis vaginae surrounded by constrictor muscle.

\section{Remarks}

In contrast to Synonchiella rotundicauda sp. nov., all other Synonchiella species are characterised by relatively long, conico-cylindrical tails with a thin cylindrical portion. $S$. minor is characterised by a relatively short conical tail ( 2.9 abd), but can be distinguished from $S$. rotundicauda sp. nov. in having smaller amphid with 1.75 turns (vs. 2.5 turns in $S$. rotundicauda sp. nov.), longer spicules (200 vs. 51 $\mu \mathrm{m})$, and more pre-cloacal supplements (42-46 vs. 8).

Genus Pseudocheironchus gen. nov. urn:Isid:zoobank.org:act:D308E75C-FF14-44AB-9DA3-E2297C691AF6

\section{Type species}

Pseudocheironchus ingluviosus gen. et sp. nov.

\section{Diagnosis}

Cuticle without lateral differentiation or only weak lateral differentiation. Outer labial sensillae and cephalic setae in one circle; cephalic setae slightly longer than outer labial sensillae. Anterior portion of buccal cavity reduced, with six thin, slightly cuticularised rhabdions; posterior buccal cavity with three equal mandibles. Pharynx short, with well-developed anterior and posterior bulbs. Male with cupshaped pre-cloacal supplements. Tail short.

\section{Etymology}

This generic name refers to the close similarity between the new genus and Cheironchus. The two genera share a feature not found in any other genus of the Selachinematidae, viz., a pharynx with conspicuous anterior and posterior bulbs.

\section{Remarks}

Pseudocheironchus gen. nov. is similar to Cheironchus in having a pharynx with well-developed anterior and posterior bulbs and cup-shaped pre-cloacal supplements. Pseudocheironchus gen. nov. differs from the latter in having a cuticle without or only weak lateral differentiation (vs. lateral differentiation of larger, irregularly spaced punctations in Cheironchus), cephalic setae only slightly longer than the outer labial sensillae ( $v S$. cephalic setae much longer than outer labia sensillae), and a posterior buccal cavity with three equal mandibles (vs. dorsal mandible reduced). Pseudocheironchus gen. nov. is also similar 

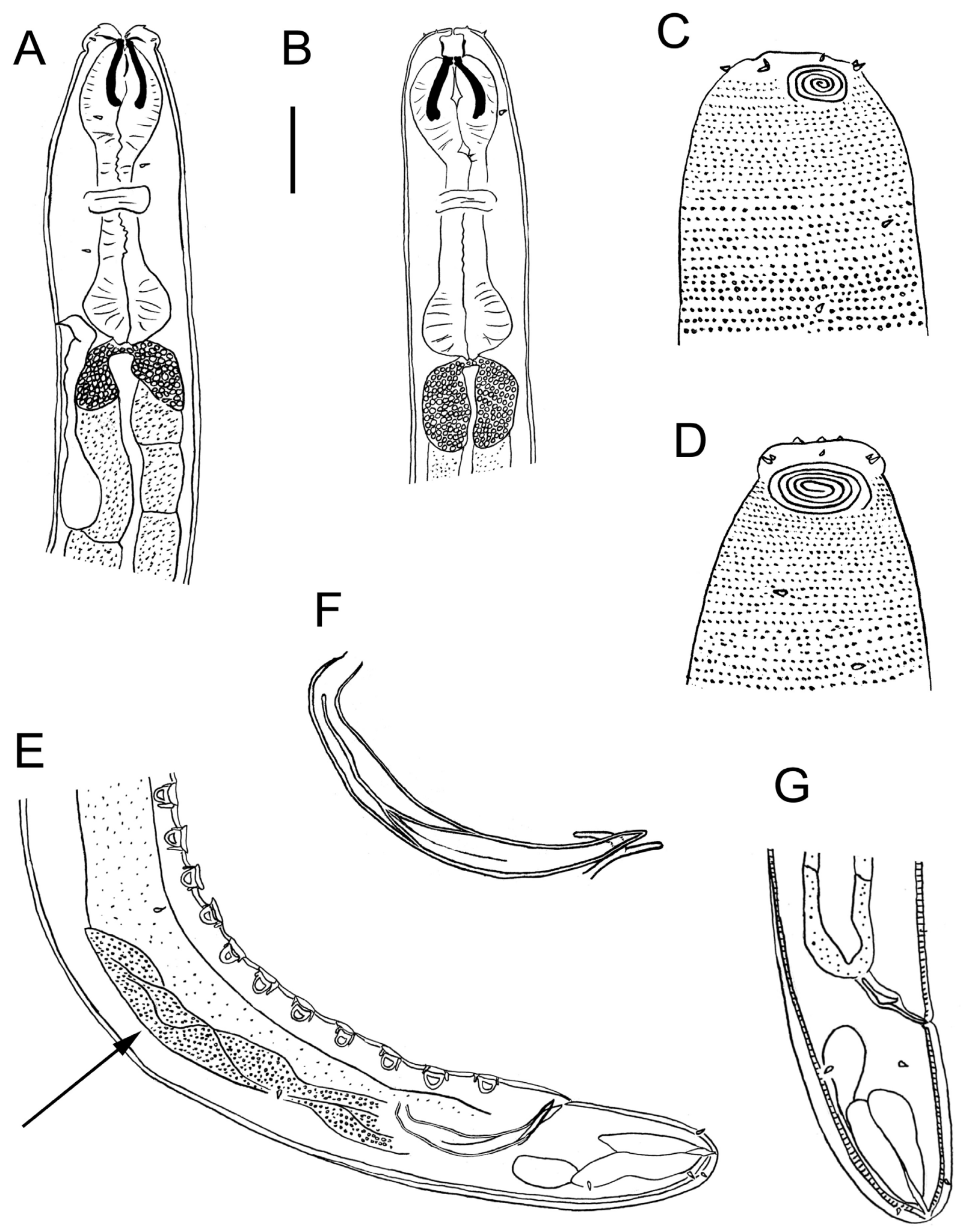

Fig. 4. Pseudocheironchus ingluviosus gen. et sp. nov. A. Lateral view of anterior body region of male. B. Sublateral view of anterior body region of female. C. Surface view of female head. D. Surface view of male head. E. Male posterior body region. F. Spicule and gubernaculum. G. Female posterior body region. Arrow shows location of ejaculatory glands. Scale bar: A-B $=25 \mu \mathrm{m} ; \mathrm{C}-\mathrm{D}=15 \mu \mathrm{m}$; $\mathrm{E}, \mathrm{G}=62 \mu \mathrm{m} ; \mathrm{F}=10 \mu \mathrm{m}$. 
to Synonchiella in having three equal mandibles in the posterior buccal cavity, but differs from the latter in having a pharynx with anterior and posterior bulbs ( $v s$. no pharyngeal bulb in Synonchiella).

Pseudocheironchus ingluviosus gen. et sp. nov.

Figs 4-7, Table 1

urn:1sid:zoobank.org:act:258E6E4A-6142-4A49-88B9-9A6E9B765309

\section{Diagnosis}

Pseudocheironchus ingluviosus gen. et sp. nov. is characterised by mandibles, each with two pairs of four blunt hooks, mandibles joined by a membrane with slender cuticularised ridges at their junction, multispiral amphideal fovea with 5.0 turns, short conical tail with rounded end, and males with spicules 1.5-1.7 abd long and 17-19 cup-shaped pre-cloacal supplements.

\section{Etymology}

The species name comes from the Latin ingluviosus (= voracious, gluttonous), and refers to the welldeveloped feeding apparatus of the species.

\section{Material examined}

\section{Holotype}

NEW ZEALAND: ${ }^{\lambda}$, NIWA 88356, 5 Apr. 2007, NIWA cruise TAN0705, station 38, western Chatham Rise crest, $43.8266^{\circ} \mathrm{S}, 176.7043^{\circ} \mathrm{E}, 478 \mathrm{~m}$, medium sand (45.3\%), fine sand (43.9\%).

\section{Paratypes}

NEW ZEALAND: 1 , , NIWA 88357, 20 Feb. 2011, NIWA cruise TAN1103, station 69, central Chatham Rise, $43.331^{\circ} \mathrm{S}, 178.288^{\circ} \mathrm{E}, 350 \mathrm{~m}$, sediment depth $1-5 \mathrm{~cm}$, mean grain size $55-59 \mu \mathrm{m}, 55-57 \%$ sand,

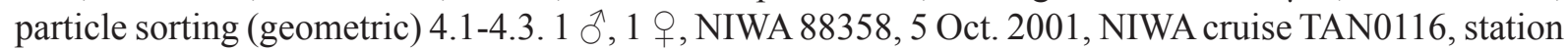
U2582, Chatham Rise crest, $43.4333^{\circ} \mathrm{S}, 178.5000^{\circ} \mathrm{E}, 350 \mathrm{~m}$, silt/clay (37.5\%), fine sand (23.4\%), medium sand $(21.4 \%)$.

A

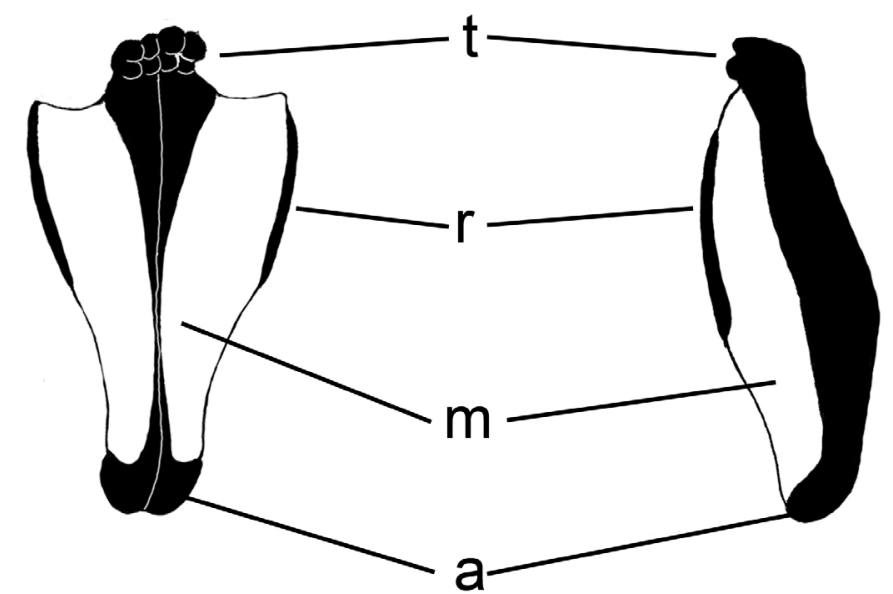

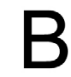

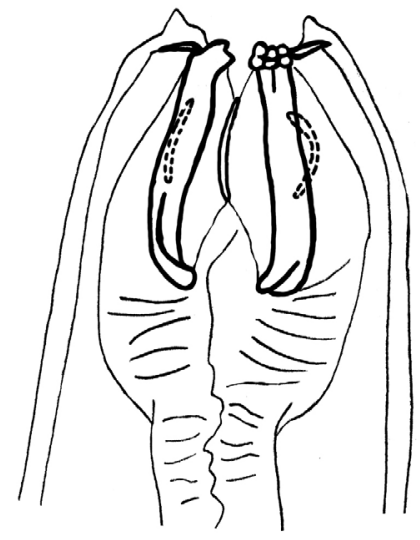

Fig. 5. Pseudocheironchus ingluviosus gen. et sp. nov. A. En face and side views (left and right, respectively) of mandibles. B. Sub-lateral view of female head showing position of mandibles and cuticularised ridges. $\mathrm{a}=$ mandible axis; $\mathrm{m}=$ membrane; $\mathrm{r}=$ cuticularised ridge; $\mathrm{t}=$ teeth. Scale bar: $\mathrm{A}=$ $10 \mu \mathrm{m} ; \mathrm{B}=20 \mu \mathrm{m}$. 


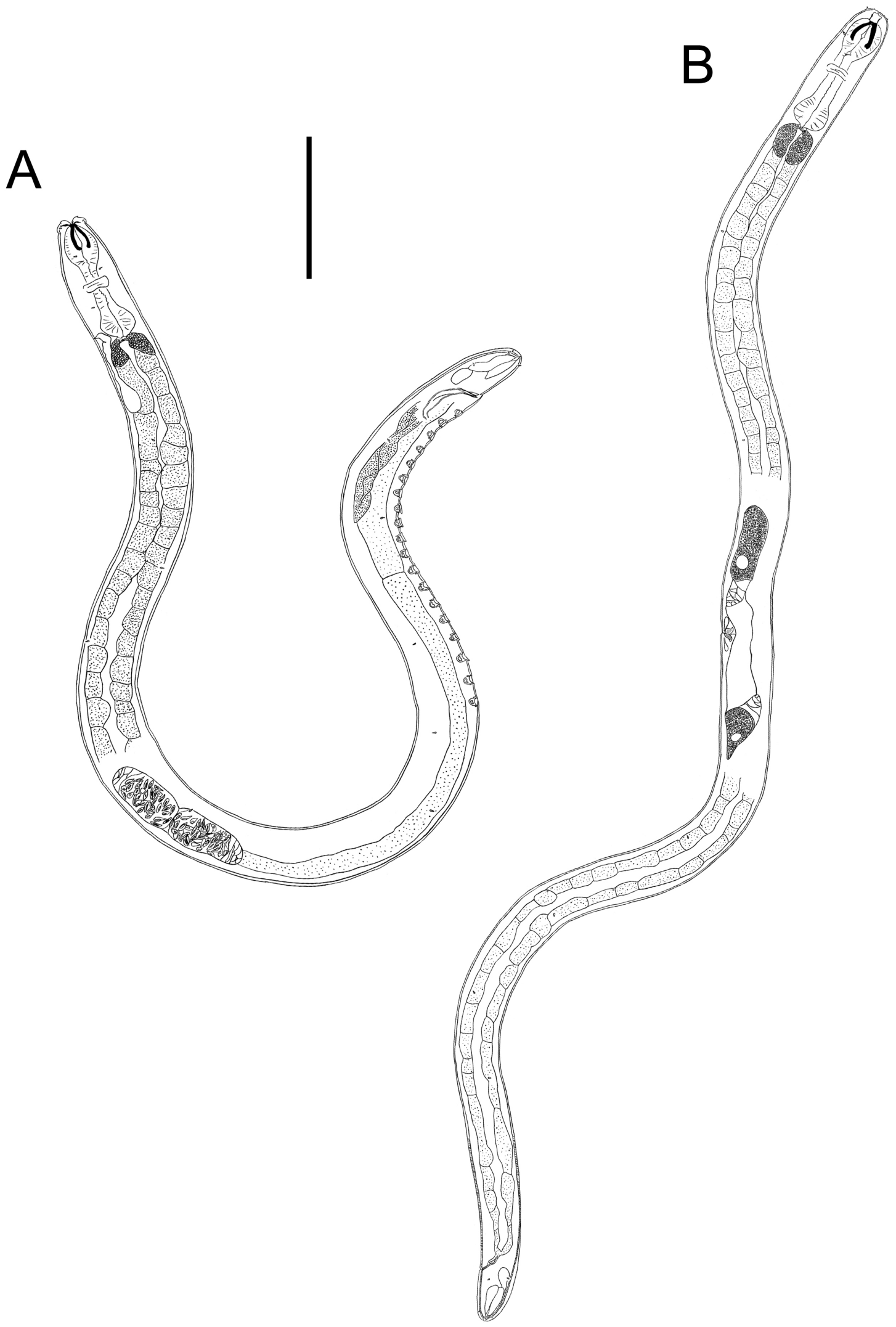

Fig. 6. Pseudocheironchus ingluviosus gen. et sp. nov. A. Entire male. B. Entire female. Scale bar $=100$ $\mu \mathrm{m}$. 

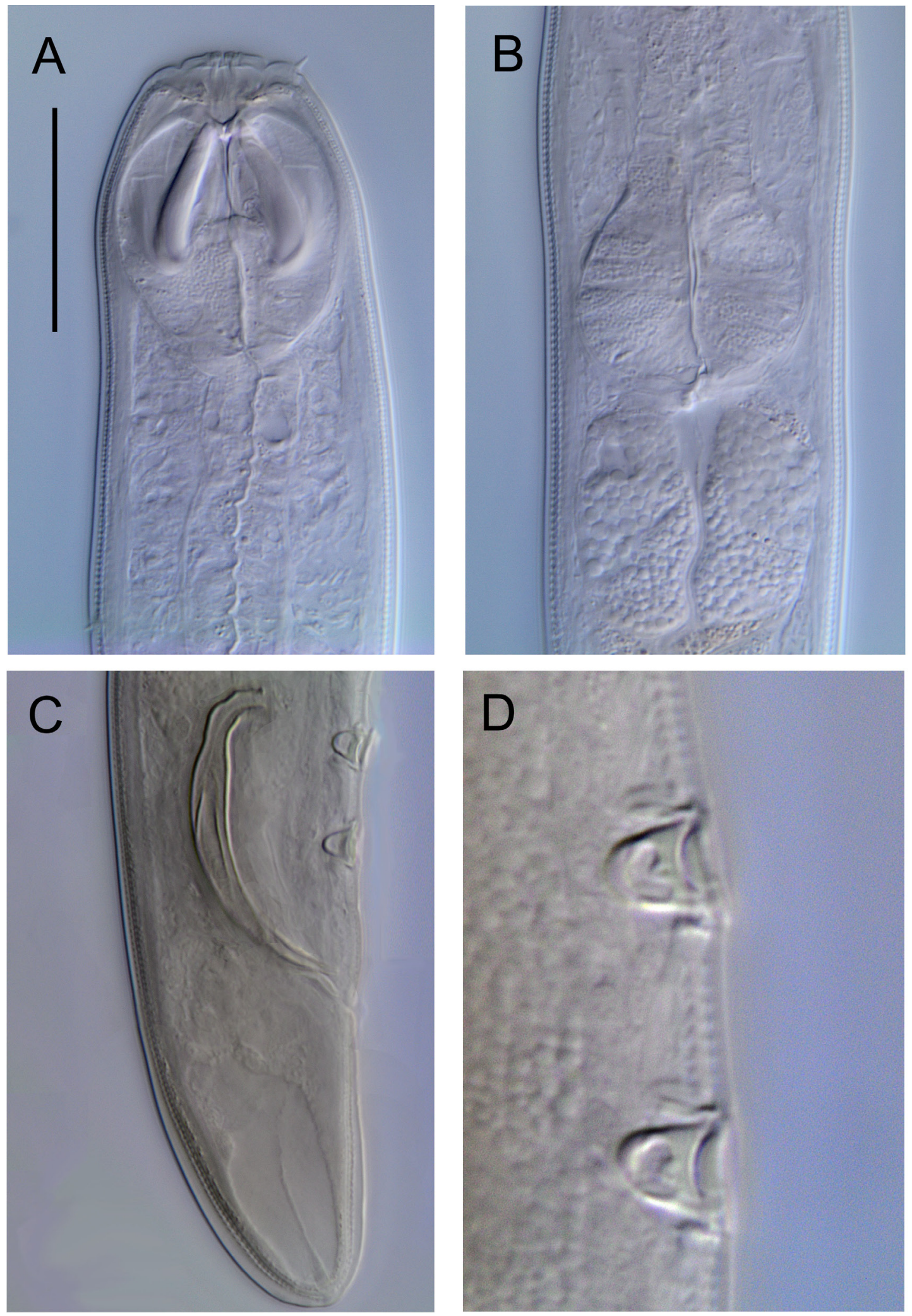

Fig. 7. Pseudocheironchus ingluviosus gen. et sp. nov. Light micrographs. A. Female head region showing buccal cavity and mandibles. B. Female posterior pharyngeal bulb and anterior portion of intestine. C. Male posterior body region showing right spicule and cup-shaped supplements. D. Detail of pre-cloacal supplements. Scale bar: A-C $=30 \mu \mathrm{m} ; \mathrm{D}=10 \mu \mathrm{m}$. 


\section{Description}

Males

Body cylindrical, tapering slightly towards both extremities. Cuticle $1.5-1.8 \mu \mathrm{m}$ thick throughout body, thicker in tail region, 3-4 $\mu \mathrm{m}$, with transverse rows of punctations, without lateral differentiation or differentiation consisting of slightly larger punctations. Somatic setae short and sparse, in four sublateral rows. Head slightly set off by constriction at level of amphid. Six conical inner labial papillae; six small outer labial setae and four slightly longer cephalic setae $(\sim 0.1 \mathrm{cbd})$ situated in one circle. Amphideal fovea situated near anterior extremity, multispiral with 5.0 turns and transversely oval outline. Anterior portion of buccal cavity short, with six pairs of thin, cuticularised rhabdions fused proximally, $\sim 6$ $\mu \mathrm{m}$ long. Posterior buccal cavity with three equal mandibles, 18-21 $\mu \mathrm{m}$ long, with one mandible situated dorsally and two sub-ventrally. Each mandible consists of a heavily cuticularised axis with a longitudinal groove (Fig. 5A); axis is thinnest in middle portion and widens towards the posterior and anterior extremities; anterior portion consists of two sets of four blunt hooks; posterior extremity of axis rounded. Two thin membranes extend laterally from the entire length of each mandible (often difficult to observe); a thin, slightly bent, cuticularised ridge is found at the junction of the membranes, one situated ventrally and two sub-dorsally (Fig. 5A, B). Pharynx short, with conspicuous oval-shaped anterior bulb surrounding posterior portion of buccal cavity, $23 \mu \mathrm{m}$ wide, $29 \mu \mathrm{m}$ long, and rounded posterior bulb, 25 $\mu \mathrm{m}$ wide. Nerve ring at middle of pharynx. Secretory-excretory (S-E) system present, cellular body of ventral gland situated $\sim 1.5$ cbd posterior to pharynx, pore situated near posterior extremity of posterior pharyngeal bulb. Intestine cells with numerous round inclusions, most dense in cells immediately posterior to pharynx (Fig. 4A).

Reproductive system diorchic with short, $\sim 50 \mu \mathrm{m}$ long, outstretched testes. Anterior testis on left of intestine, posterior testis on right of intestine. Small, nucleated sperm cells, oval or elongated with pointed ends, $\sim 6 \times 2 \mu \mathrm{m}$. Spicules paired, curved, 1.5-1.7 abd long, widest in middle portion and tapering distally. Gubernaculum small, slightly bent, median part (cuneus) with hook-shaped projection pointing dorsally (Fig. 4F). Three, perhaps four pairs of ejaculatory glands situated anterior to spicules (Fig. 4E). Mid-ventral row of 17-19 cup-shaped pre-cloacal supplements, $\sim 5 \mu \mathrm{m}$ wide and $5 \mu \mathrm{m}$ deep, situated 5-8 $\mu \mathrm{m}$ apart. Pre-cloacal supplements thickly cuticularised, with nerve entering anterior side of cup. No pre-cloacal seta observed. Post-cloacal setae/papillae not observed. Tail short, conical, with rounded posterior extremity and three small terminal setae. Three caudal glands and small spinneret present.

\section{Females}

Similar to males, but with smaller amphideal fovea with circular outline. Reproductive system didelphic-amphidelphic with reflexed ovaries. Anterior ovary on left of intestine, posterior ovary on right of intestine. Vulva located slightly pre-median. Vaginal glands present, pars proximalis vaginae surrounded by constrictor muscle.

Subfamily Choniolaiminae Schuurmans-Stekhoven \& Adam, 1931

\section{Diagnosis}

Buccal cavity with broad, cup-shaped anterior portion and relatively narrow posterior portion, both reinforced by radially arranged, cuticularised rhabdions. Mandibles absent.

\section{Valid genera}

Choniolaimus Ditlevsen, 1921

Choanolaimus De Man, 1880

Cobbionema Filipjev, 1922 
Gammanema Cobb, 1920

Halichoanolaimus De Man, 1886

Latronema Wieser, 1954

\title{
Type species
}

Genus Cobbionema Filipjev, 1922

Cobbionema acrocerca Filipjev, 1922

\section{Diagnosis}

Four cephalic setae conspicuously longer than the outer labial sensillae, buccal cavity surrounded by anterior pharyngeal bulb. Male with two testes pointing anteriorly and reflexed posterior testis. Short conico-cylindrical tail.

\section{Remarks}

Cobbionema cylindrilaimoides (Schuurmans-Stekhoven, 1950) was synonymised with C. acrocerca by Gerlach (1964) in his review of the Selachinematidae. Species descriptions were until now all based on female specimens only.

\section{Valid species}

C. acrocerca Filipjev, 1922

C. capense Furstenberg \& Vincx, 1987

\author{
Cobbionema trigamma sp. nov. \\ Figs. 8-10, Table 2 \\ urn:1sid:zoobank.org:act:06CDA8B6-C525-46E9-9D04-05C4923651D8
}

\section{Diagnosis}

Cobbionema trigamma sp. nov. is characterised by four long cephalic setae and six smaller outer labial setae in one circle, amphideal fovea with 4.25 turns, six rhabdions surrounding anterior buccal cavity, each with two pairs of pointed projections at their posterior extremities, posterior buccal cavity widening posteriorly and with three pairs of rhabdions fused posteriorly and widening anteriorly, males with two testes pointing anteriorly and with reflexed posterior testis, spicules 2.5 abd long, and no pre-cloacal supplements.

\section{Etymology}

The species name is derived from the Greek letter $\gamma$ (gamma), and refers to the presence of three pairs of rhabdions fused posteriorly (i.e., gamma-shaped) in the posterior buccal cavity.

\section{Material examined}

\section{Holotype}

NEW ZEALAND: 今ึ, NIWA 88359, 6 Apr. 2007, NIWA cruise TAN0705, station 45, southern flank of Chatham Rise, $44.4864^{\circ} \mathrm{S}, 177.1407^{\circ} \mathrm{E}, 1238 \mathrm{~m}$, silt/clay (93.9\%).

\section{Paratypes}

NEW ZEALAND: 1 đ, NIWA 88360, 8 Oct. 2001, TAN0116, station U2593A, southern flank of Chatham Rise, $44.3333^{\circ} \mathrm{S}, 178.5000^{\circ} \mathrm{E}, 1200 \mathrm{~m}$, silt/clay (63.8\%), fine sand (16.0\%), very fine sand (13.6\%). 1 , NIWA 88361, 26 Apr. 2007, NIWA cruise TAN0705, station 271, northern flank of Chatham Rise, $42.6216^{\circ} \mathrm{S}, 175.9262^{\circ} \mathrm{E}, 1210 \mathrm{~m}$, fine sand $(60.3 \%)$, medium sand $(29.3 \%)$. 

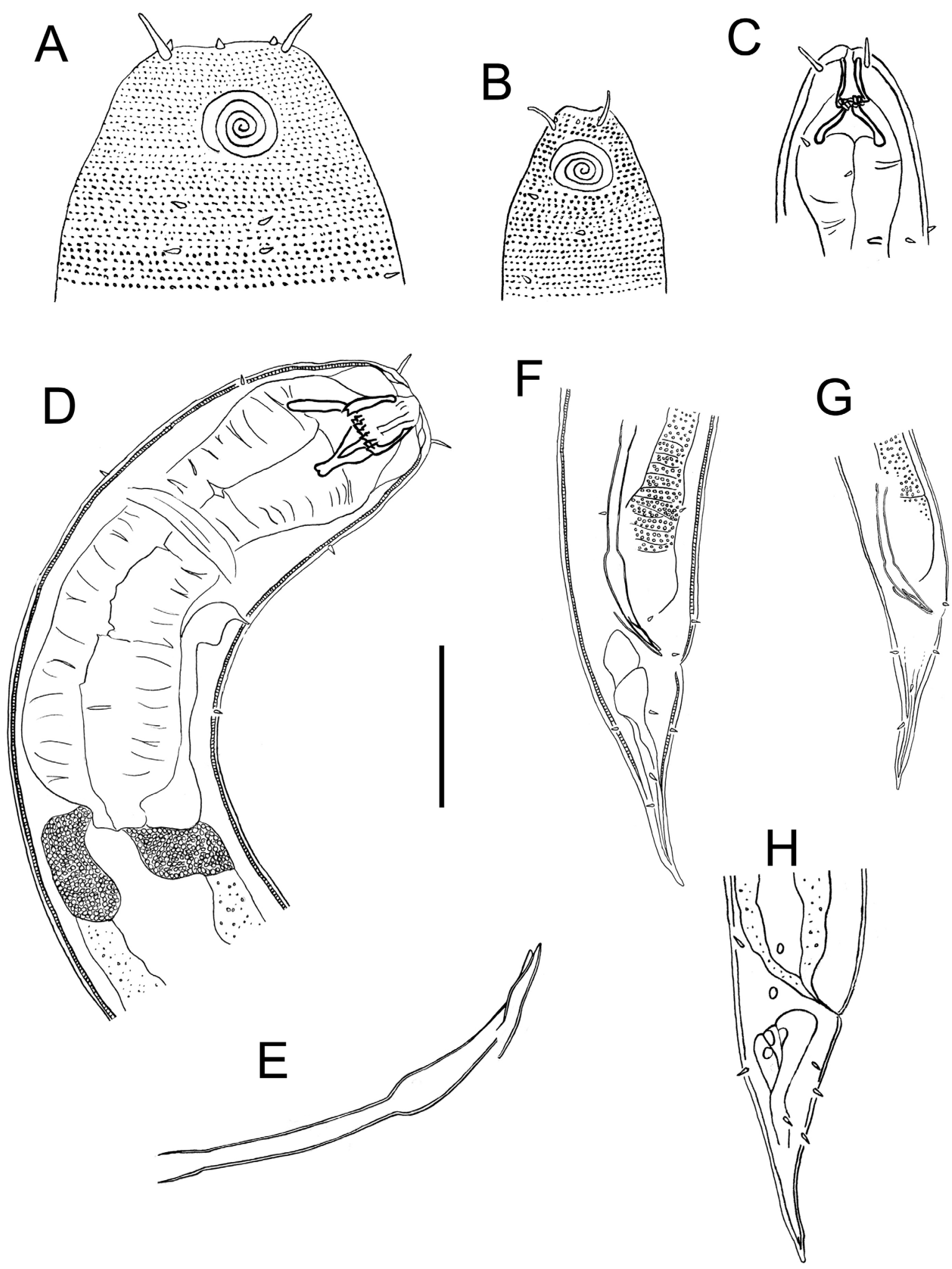

Fig. 8. Cobbionema trigamma sp. nov. A. Surface view of holotype head. B. Surface view of paratype male head. C. Buccal cavity of paratype male. D. Holotype anterior body region. E. Spicule and gubernaculum of holotype. F. Holotype posterior body region. G. Paratype male posterior body region. H. Female posterior body region. Scale bar: A-C $=30 \mu \mathrm{m} ; \mathrm{D}=80 \mu \mathrm{m} ; \mathrm{E}=36 \mu \mathrm{m} ; \mathrm{F}-\mathrm{G}=70 \mu \mathrm{m} ; \mathrm{H}=$ $40 \mu \mathrm{m}$. 


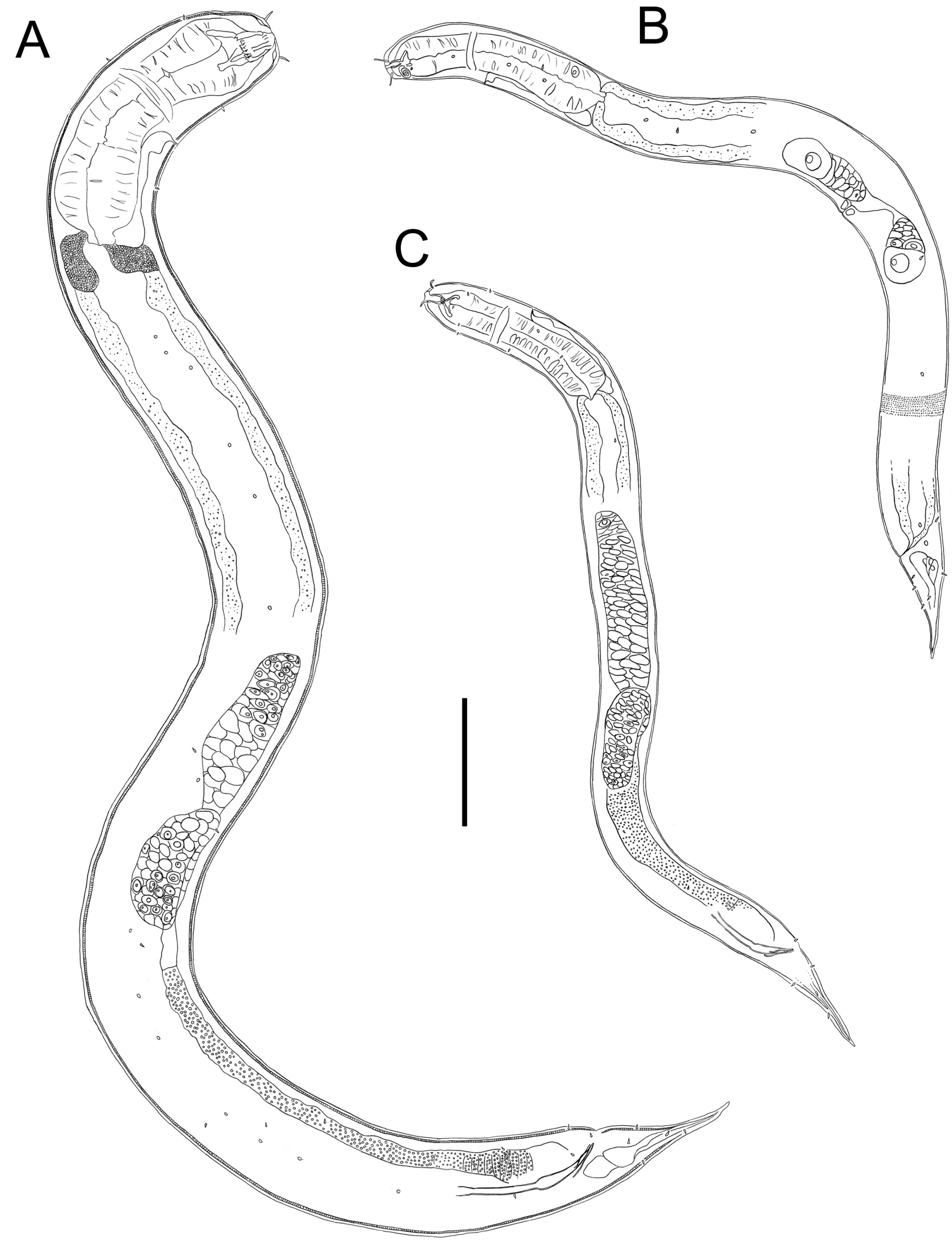

Fig. 9. Cobbionema trigamma sp. nov. A. Entire holotype. B. Entire female. C. Entire male paratype. Scale bar $=100 \mu \mathrm{m}$. 


\section{Description}

Males

Body cylindrical, tapering slightly towards both extremities. Cuticle 1.5-3.0 $\mu \mathrm{m}$ thick, thickest in tail region, with transverse rows of punctations, without lateral differentiation except in mid-body region, where punctations are irregularly spaced and further apart; lateral rows of oval-shaped cuticle pores, 1.5$2 \times 2-3 \mu \mathrm{m}$, beginning from halfway down pharynx to anterior portion of tail (Fig. 10B). Somatic setae short and sparse, irregularly distributed. Head blunt, not set off, with six lips surrounding mouth opening. Inner labial papillae minute; six small outer labial setae situated slightly anterior to four conspicuously longer cephalic setae, 0.3-0.5 cbd. Amphideal fovea multispiral with 4.25 turns, with circular outline. Buccal cavity voluminous, divided into anterior and posterior portion. Anterior portion of buccal cavity cylindrical, with six cuticularised rhabdions, each with two pairs of large, pointed projections at posterior extremity (Fig. 10A). Posterior buccal cavity cone-shaped, widest at posterior extremity, with three pairs of rhabdions fused posteriorly and gradually widening anteriorly (Fig. 10A). Pharynx with conspicuous anterior bulb surrounding posterior portion of buccal cavity and part of anterior buccal cavity; pharynx widens posteriorly but not forming true posterior bulb. Nerve ring at $45 \%$ of pharynx length from anterior. Secretory-excretory (S-E) system present, cellular body of ventral gland situated immediately posterior to pharynx, pore situated $0.1-0.5 \mathrm{cbd}$ posterior to nerve ring. Intestine cells with numerous round inclusions, most dense in cells immediately posterior to pharynx (Fig. 8D).

Reproductive system with two testes pointing anteriorly, with outstretched anterior testis and reflected posterior testis. Anterior testis on left of intestine, posterior testis on right of intestine. Large globular sperm cells, 6-9 $\times 10-13 \mu \mathrm{m}$. Spicules paired, 2.5 abd long, curved, swollen at proximal end and at $55 \%$ of spicule length from proximal portion, then tapering distally. Gubernaculum bent, with lateral pieces (crurae) flanking distal ends of spicules. Pre-cloacal supplements absent; one small pre-cloacal seta. Tail conico-cylindrical with short, sparse setae and pointed extremity. Three caudal glands and spinneret present.

\section{Female}

Similar to male. Reproductive system didelphic-amphidelphic with reflected ovaries. Anterior ovary on left of intestine, posterior ovary on right of intestine. Vulva located at $\sim 40 \%$ of body length from anterior
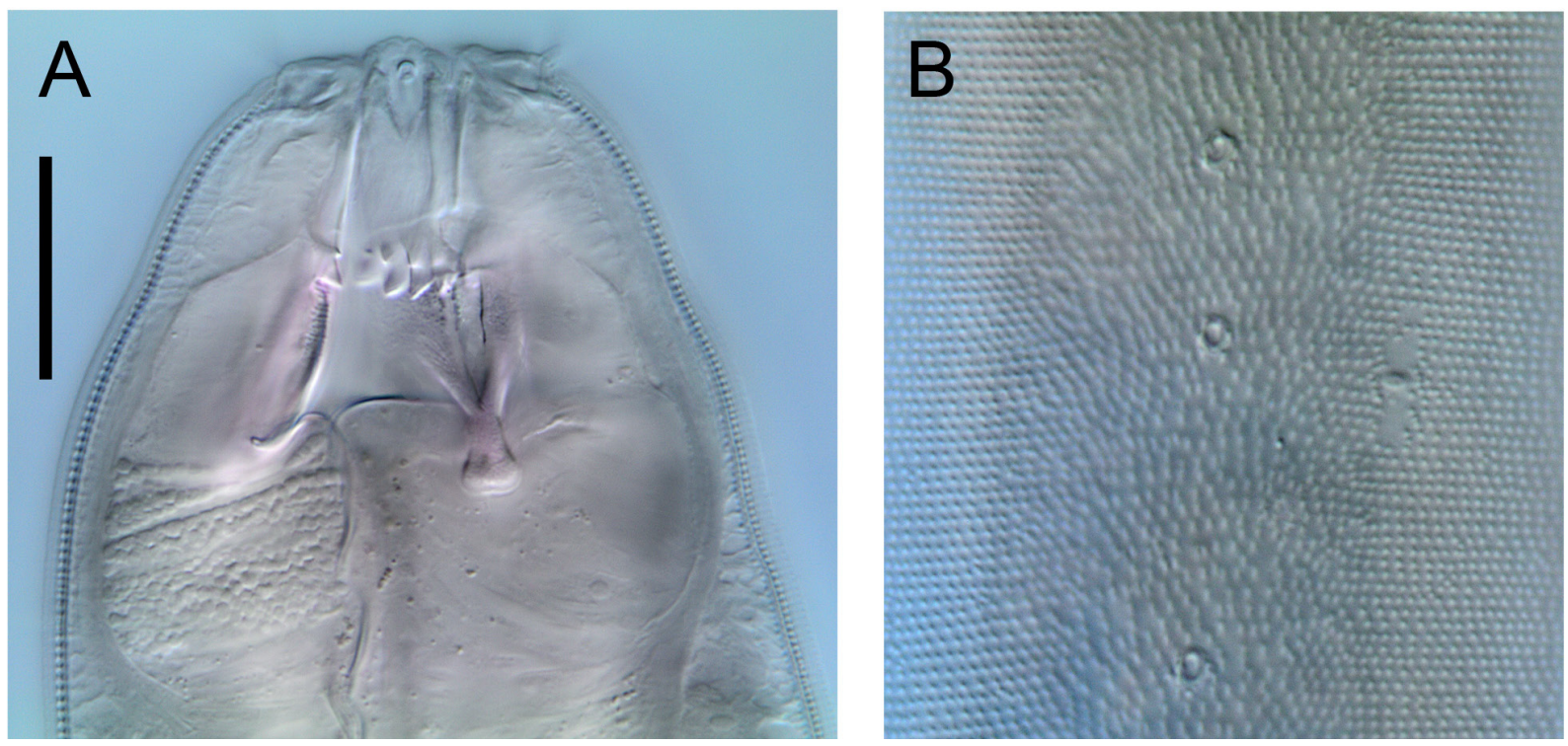

Fig. 10. Cobbionema trigamma sp. nov. Light micrographs. A. Buccal cavity of holotype. B. Cuticle of holotype, showing cuticle pores. Scale bar: A $=25 \mu \mathrm{m} ; \mathrm{B}=12 \mu \mathrm{m}$. 
extremity. Pars proximalis vaginae surrounded by constrictor muscle, vaginal glands not observed. Anus not observed.

\section{Remarks}

Cobbionema trigamma sp. nov. is similar to C. acrocerca but differs from the latter in having a posterior buccal cavity with three pairs of rhabdions fused posteriorly and widening anteriorly, whereas C. acrocerca possesses a posterior buccal cavity with three irregularly-spaced rhabdions narrowing posteriorly and bearing hooks at their anterior extremities. C. trigamma sp. nov. differs from C. capense in the absence of denticles in the buccal cavity, and in the number (24 in C.trigamma sp. nov. vs. 7 in $C$. capense) and orientation of pointed projections (all pointing posteriorly vs. some pointing anteriorly in C. capense; pointed projections referred to as "teeth" in Furstenberg \& Heyns 1987).

There was a substantial ( $>2$-fold) difference in size between the holotype and the paratype male. The two males also differed in the size of the amphid (0.28 vs. $0.52 \mathrm{cbd})$ and tail length (2.2. vs. $2.8 \mathrm{abd})$, but were identical in the size and arrangement of head sensillae, buccal cavity structure, and copulatory apparatus.

The buccal cavity of Cobbionema trigamma sp. nov. closely resembles that of Halichoanolaimus. H. robustus (Bastian, 1865), H. consimilis Allgén, 1933, H. quattuordecimpapillatus Chitwood, 1951 and $H$. dolichurus Ssaweljev, 1912, for example, all have an anterior buccal cavity surrounded by rhabdions with pointed projections or hooks (the latter often in pairs) and a posterior buccal cavity surrounded by three pairs of rhabdions fused posteriorly (see figs 6-9 in Gerlach 1964).

The female of Cobbionema trigamma sp. nov. appears to lack an anus, a feature that has also been observed in several Halichoanolaimus species (Gourbault \& Vincx 1985). The absence of an anus was also noted by Schuurmans-Stekhoven (1950) in C. cylindrolaimoides ("the anal cleft could not be located"). The latter author cast doubt on the observations of Filipjev (1922), who drew the anus of $C$. acrocerca very far posteriorly near the cylindrical portion of the tail, which could suggest that the anus is in fact absent in C. acrocerca as well.

Cobbionema trigamma sp. nov. is unusual among the Selachinematidae in the structure of the testes (two testes anteriorly with posterior testis reflexed), and Choniolaiminae in lacking pre-cloacal supplements. Because this is the first time that male Cobbionema specimens are described, it remains unclear whether these are characteristic of other species of the genus.

\section{Type species}

Genus Gammanema Cobb, 1920

Gammanema ferox Cobb, 1920 (junior synonym of Gammanema rapax (Ssaweljev, 1912)).

\section{Diagnosis}

Cuticle without lateral differentiation, four slender cephalic setae; outer labia either papillose or setose. Amphideal fovea usually spiral, rarely loop-shaped. Anterior buccal cavity large, cup-shaped, surrounded by rhabdions with pointed projections at their posterior ends; posterior buccal cavity smaller, often with broad column-shaped rhabdions. Pharynx without anterior or posterior bulb. Pre-cloacal supplements present, usually cup-shaped, rarely setose or tubular. Short conical tail.

\section{Remarks}

Gammanema paramenzeli (Allgén, 1935) was considered doubtful by Gerlach (1964), Trogolaimus uniformis Cobb, 1920 was transferred to Gammanema by Tchesunov \& Okhlopkov (2006) and G. fennicum Gerlach, 1953 was re-established as a valid species by Okhlopkov (2002). 


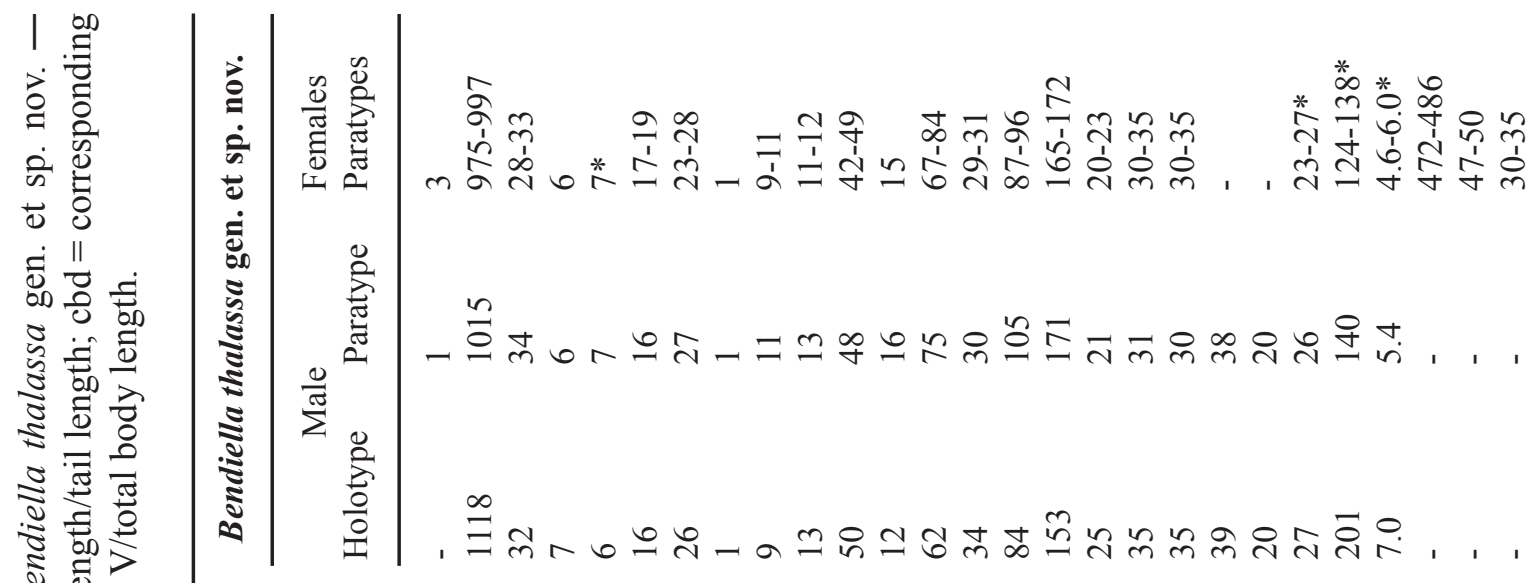
$\infty$ 네

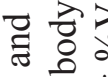

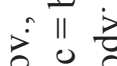

$\circ \circ$

궁

दे $\overline{0}$

帘

离

के है त

施

$\cong$ ฮ

究

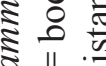

811

$\therefore$

잉

के.

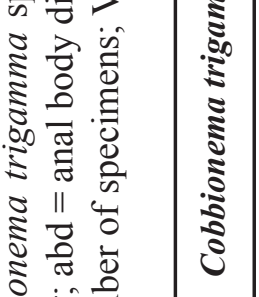

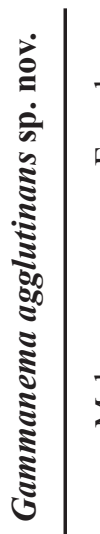

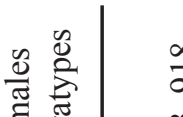

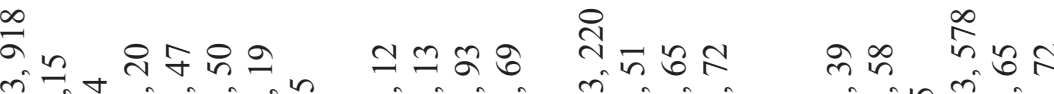

政 、

竞

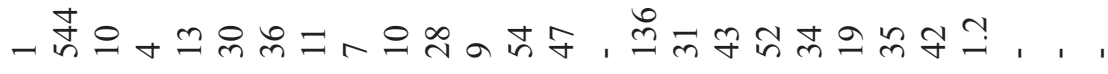

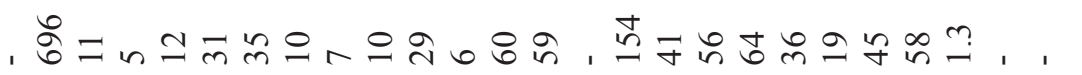

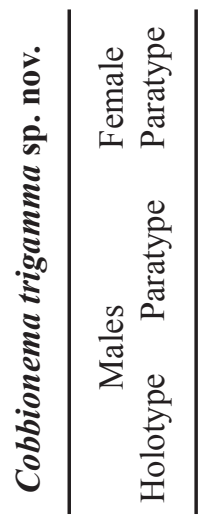

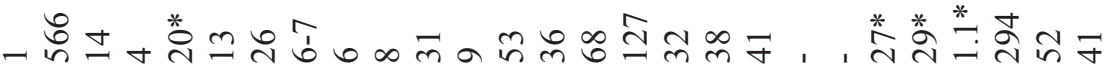

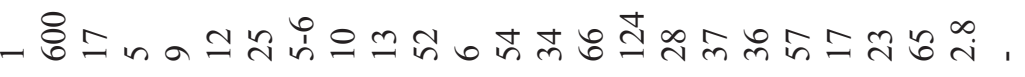

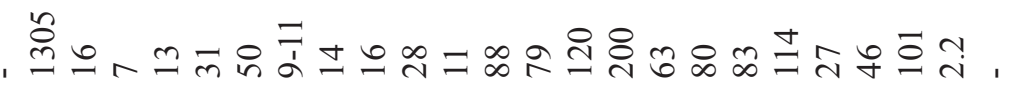

$\frac{\pi}{4}$

$4: 7=$

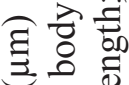

E을

语言 


\author{
Valid species \\ G. anthostoma Okhlopkov, 2002 \\ G. cancellatum Gerlach, 1955 \\ G. curvata Gagarin \& Klerman, 2007 \\ G. conicauda Gerlach, 1953 \\ G. fennicum Gerlach, 1953 \\ G. kosswigi Gerlach, 1964 \\ G. mediterraneum Vitiello, 1970 \\ G. polydonta Murphy, 1965 \\ G. rapax (Ssaweljev, 1912) \\ G. smithi Murphy, 1964 \\ G. tchesunovi Gagarin \& Klerman, 2007 \\ G. uniformis (Cobb, 1920)
}

Gammanema agglutinans sp. nov.

Figs 11-13, Table 2

urn:1sid:zoobank.org:act:3AEBAD01-7722-489F-B9FF-818C5B1B8617

\title{
Diagnosis
}

Gammanema agglutinans sp. nov. is characterised by short, stout body $(\mathrm{a}=10-15)$, cuticle with minute spines, leaf-shaped somatic setae with ducts, sexual dimorphism in the shape of the amphideal fovea (loop-shaped in males and spiral in females), posterior buccal cavity with three pairs of broad, columnshaped rhabdions fused anteriorly, intestine cells conspicuous with orange-brown granules, slightly curved spicules, 0.8-1.0 abd long, and small tubular pre-cloacal supplements.

\section{Etymology}

The species name is derived from the Latin word glutino (= glue, paste together) and refers to the mucus and debris adhering to cuticle of this species.

\section{Material examined}

\section{Holotype}

NEW ZEALAND: ${ }^{\lambda}$, NIWA 88362, 20 Feb. 2011, NIWA cruise TAN1103, station 69, central Chatham Rise, $43.331^{\circ} \mathrm{S}, 178.288^{\circ} \mathrm{E}, 350 \mathrm{~m}$, sediment depth $1-5 \mathrm{~cm}$, mean grain size $55-59 \mu \mathrm{m}, 55-57 \%$ sand, particle sorting (geometric) 4.1-4.3.

\section{Paratypes}

NEW ZEALAND: 1 đ, 1 q, NIWA 88363, same data as holotype. 1 \& NIWA 88364, 6 Apr. 2007, NIWA cruise TAN0705, station 45, southern flank of Chatham Rise, $44.4864^{\circ} \mathrm{S}, 177.1407^{\circ} \mathrm{E}, 1238 \mathrm{~m}$, silt/clay $(93.9 \%)$.

\section{Description}

\section{Males}

Body short, stout, cylindrical, tapering slightly towards anterior extremity, covered with thin layer of adhering mucus and small detrital particles. Cuticle $\sim 1.0-1.5 \mu \mathrm{m}$ thick, with transverse rows of punctations, without lateral differentiation, each punctation terminating into a minute spine (spines often difficult to observe due to presence of adhering particles). Four sub-lateral rows of leaf-shaped somatic setae (i.e., with narrow base, wide middle portion, and tapering distal end), each with a central duct, 

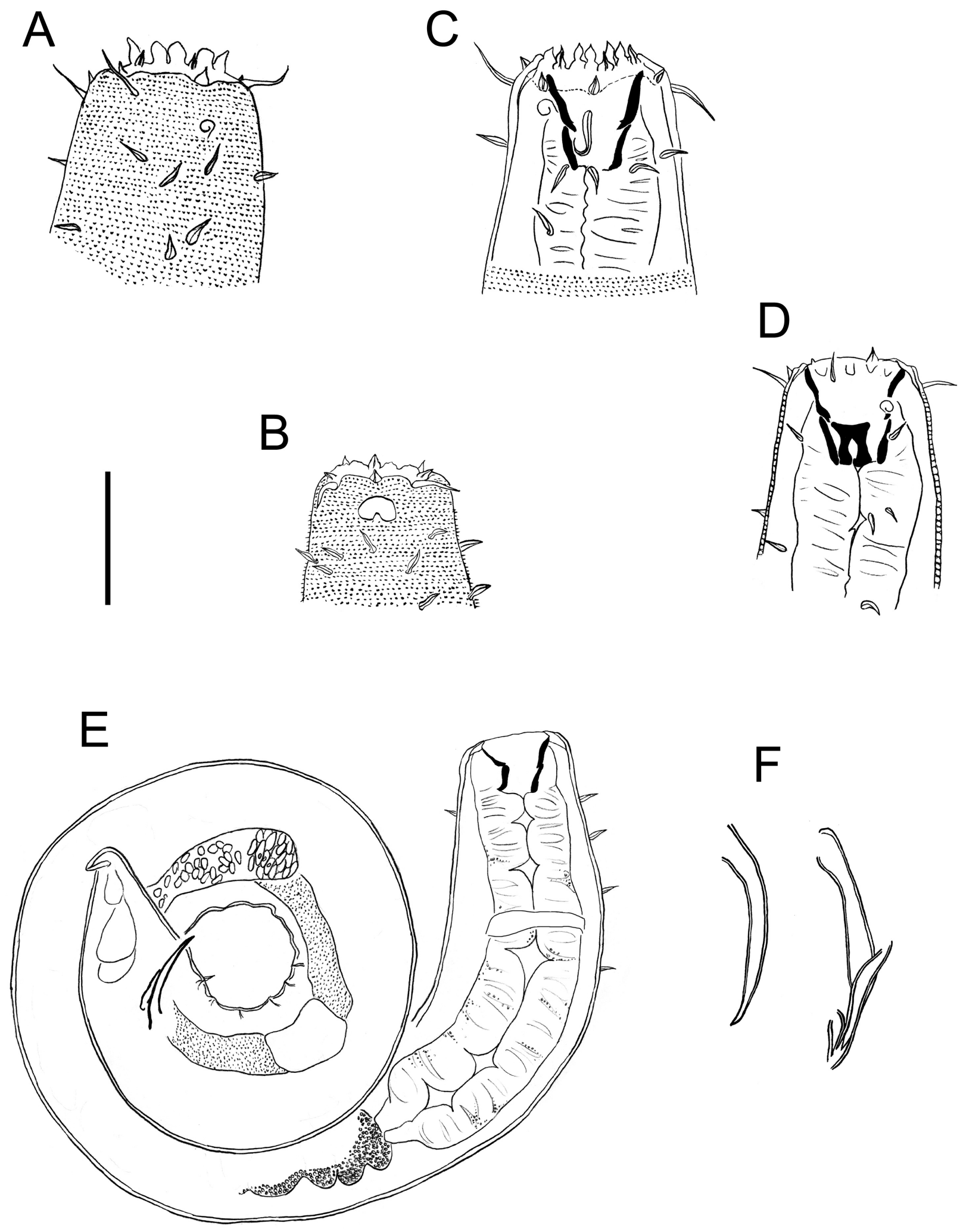

\section{$\mathrm{F}$}

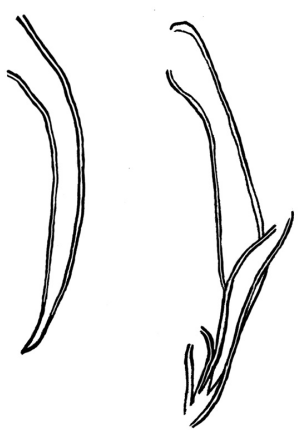

Fig. 11. Gammanema agglutinans sp. nov. A. Surface view of female head. B. Surface view of male head. C. Female head, showing buccal cavity. D. Female head, showing buccal cavity. E. Entire male. F. Spicule and gubernaculum. Scale bar: A-D $=30 \mu \mathrm{m} ; \mathrm{E}=40 \mu \mathrm{m} ; \mathrm{F}=18 \mu \mathrm{m}$. 
4-8 $\mu \mathrm{m}$ long and $2 \mu \mathrm{m}$ wide (Fig. 13E). Head blunt, only slightly rounded, not set off. Mouth opening surrounded by six pairs of thin, leaf-shaped cuticle extensions, 3-4 $\mu \mathrm{m}$ long (Fig. 11A, B). Labial sensillae in three separate circles; inner and outer labial setae conical, $\sim 2 \mu \mathrm{m}$ long, each with central duct; four cephalic setae, each with central duct, $<0.3 \mathrm{cbd}$. Loop-shaped amphideal fovea, situated $<0.2$ cbd from anterior extremity. Buccal cavity divided into anterior and posterior portions; anterior portion of buccal cavity large, funnel-shaped, with twelve cuticularised rhabdions, each with one pair of pointed

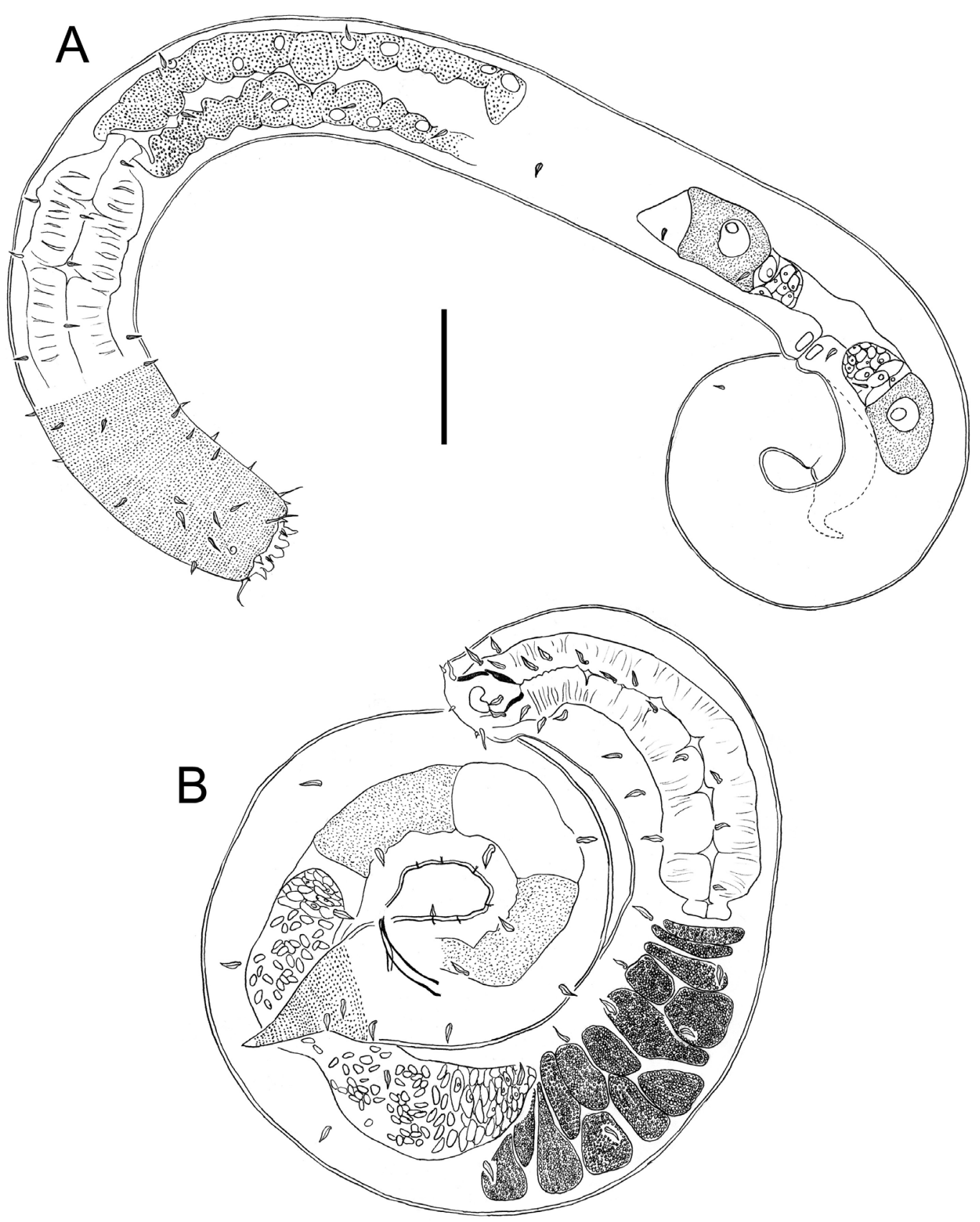

Fig. 12. Gammanema agglutinans sp. nov. A. Entire female. B. Entire male. Scale bar: $A=60 \mu \mathrm{m} ; \mathrm{B}=$ $50 \mu \mathrm{m}$. 
projections at posterior extremity (Fig. 13D). Posterior buccal cavity narrow, cylindrical, surrounded by three pairs of broad, column-shaped rhabdions fused in anterior half (Fig. 13B). Pharynx without anterior bulb; pharynx widens posteriorly but not forming true posterior bulb. Nerve ring at $\sim 40 \%$ of
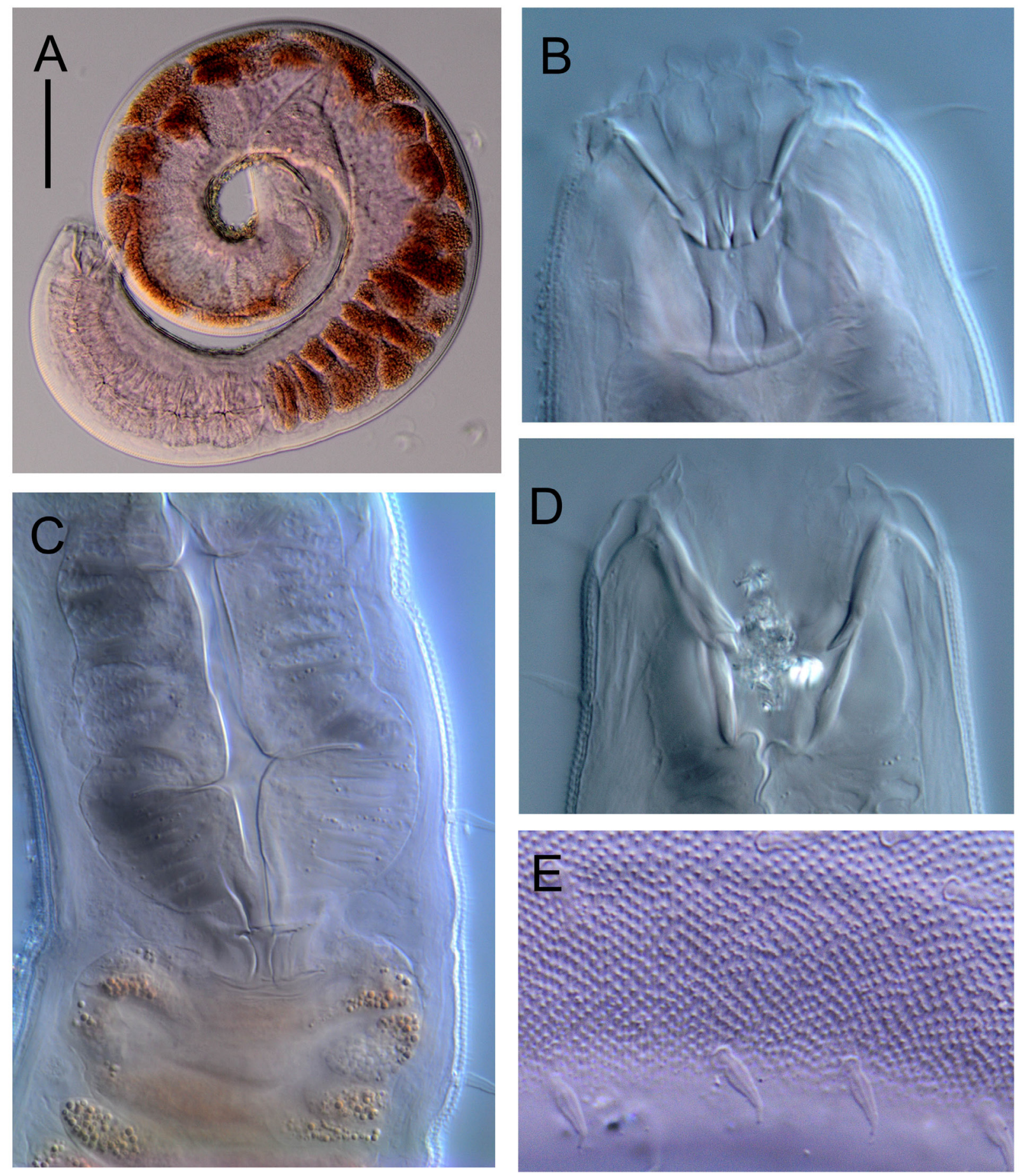

Fig. 13. Gammanema agglutinans sp. nov. Light micrographs. A. Entire male. B. Buccal cavity of female, showing paired rhabdions in posterior buccal cavity. C. Posterior region of pharynx, cardia, and anterior region of intestine of female. D. Buccal cavity of female, showing pointed projections at posterior extremity of rhabdions in anterior buccal cavity. E. Cuticle of male, showing punctations, spines, and somatic setae. Scale bar $\mathrm{A}=30 \mu \mathrm{m} ; \mathrm{B}, \mathrm{D}=15 \mu \mathrm{m} ; \mathrm{C}=12 \mu \mathrm{m} ; \mathrm{E}=7 \mu \mathrm{m}$. 
pharynx length from anterior. Secretory-excretory (S-E) system not observed. Intestine cells large, welldefined, with numerous round, orange-brown inclusions (Fig. 13A).

Reproductive system diorchic with short, outsretched testes. Testes situated either both ventrally or with anterior testis on left of intestine and posterior testis on right of intestine; small, globular to oval-shaped sperm cells, 2-4 $\times 5 \mu \mathrm{m}$. Spicules paired, 0.8-1.0 abd long, slightly curved, with slight constriction near proximal extremity and tapering distally. Gubernaculum small, slightly bent at proximal end, with lateral pieces (crurae) flanking the distal end of the spicules and a small cuneus with two small, drop-shaped projections anteriorly (not visible in paratype male). At least six small tubular pre-cloacal supplements, difficult to observe due to adhering particles; pre-cloacal seta present. Tail short, conical, with few sparse sub-dorsal setae. Three caudal glands and spinneret present.

\section{Females}

Similar to male, but with conspicuously smaller spiral amphideal fovea, 1.5 turns. Reproductive system didelphic-amphidelphic, with reflected ovaries. Anterior ovary on left of intestine, posterior ovary on right of intestine. Vulva located at two thirds of body length from anterior extremity. Pars proximalis vaginae surrounded by constrictor muscle, vaginal glands not observed.

\section{Remarks}

G. agglutinans sp. nov. differs from all other species in the genus in having a cuticle with spines (vs. spines absent in all other species), males with loop-shaped amphids (vs. multispiral amphids) and leafshaped somatic setae with ducts (vs. slender setae without ducts). In addition, species of the genus are characterised by either cup-shaped or setose pre-cloacal supplements, whereas G. agglutinans sp. nov. is characterised by tubular supplements.

Genus Bendiella gen. nov.

urn:1sid:zoobank.org:act:8E1879A0-8BBA-4564-AAC8-E6BF123EDF0E

\section{Type species}

Bendiella thalassa gen. et sp. nov.

\section{Diagnosis}

Cuticle with lateral differentiation in the form of longitudinal rows of larger punctations. Outer labial sensillae and cephalic setae in one circle; cephalic setae slightly longer than outer labial sensillae. Buccal cavity large; anterior portion of buccal cavity cylindrical to funnel-shaped, with twelve cuticularised rhabdions, each with pointed projections at posterior extremity. Posterior buccal cavity narrower, cylindrical, surrounded by three Y-shaped pairs of slender rhabdions. Pre-cloacal supplements absent. Tail long.

\section{Etymology}

The genus is named after Bendis, the Thracian goddess of the hunt.

\section{Remarks}

Bendiella gen. nov. is most similar to Halichoanolaimus in the shape and arrangement of the head sensillae, structure of the buccal cavity, and in having a relatively long tail. Bendiella gen. nov. differs from the latter, and from all other genera of the family Selachinematidae, in having a cuticle with lateral differentiation consisting of longitudinal rows of larger dots, and from all other genera of the Choniolaiminae (except the species Gammanema anthostoma Okhlopkov, 2002) in lacking pre-cloacal supplements. 

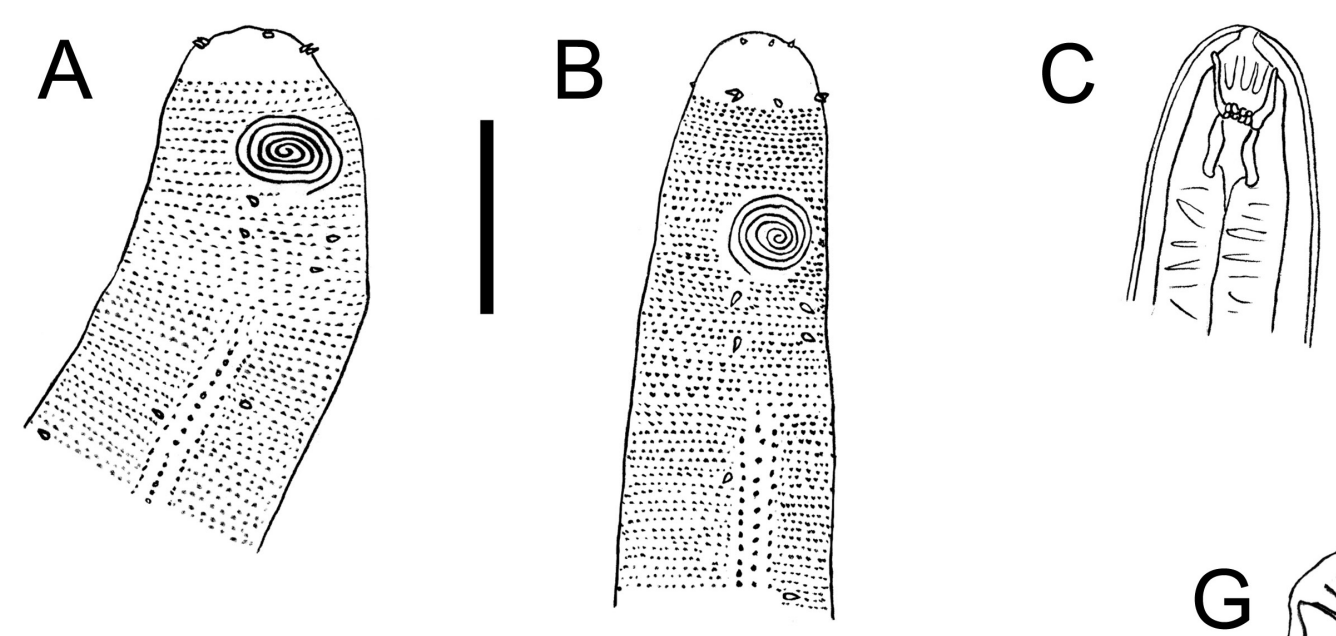

$\mathrm{D}$
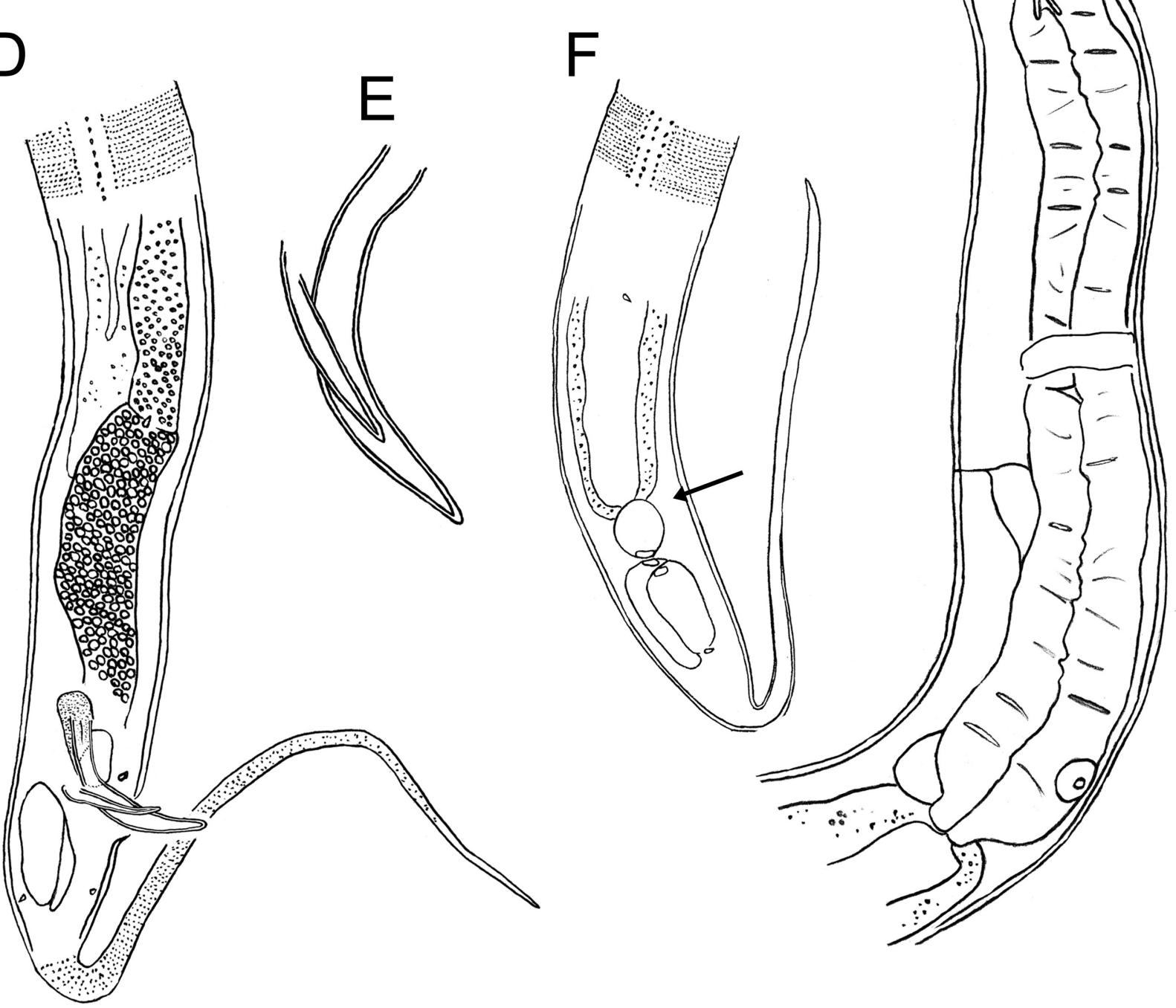

Fig. 14. Bendiella thalassa gen. et sp. nov. A. Surface view of male head. B. Surface view of female head. C. Female head, showing buccal cavity. D. Posterior body region of male. E. Spicule and gubernaculum. F. Posterior body region of female. G. Anterior body region of male. Arrow shows position of lateral hypodermal gland near posterior end of intestine. Scale bar: A-C, $G=25 \mu \mathrm{m} ; \mathrm{D}, \mathrm{F}=32 \mu \mathrm{m}$; $\mathrm{E}=13 \mu \mathrm{m}$. 


\section{Bendiella thalassa gen. et sp. nov. \\ Figs. 14-16, Table 2 \\ urn:Isid:zoobank.org:act:31AB5540-964C-41F2-B592-F329369969DC}

\section{Diagnosis}

Bendiella thalassa gen. et sp. nov. is characterised by amphideal fovea with 5.25 turns, anterior buccal cavity with twelve rhabdions, each with a pair of pointed projections at posterior extremity, posterior buccal cavity with three Y-shaped pairs of slender rhabdions fused from two thirds of distance from
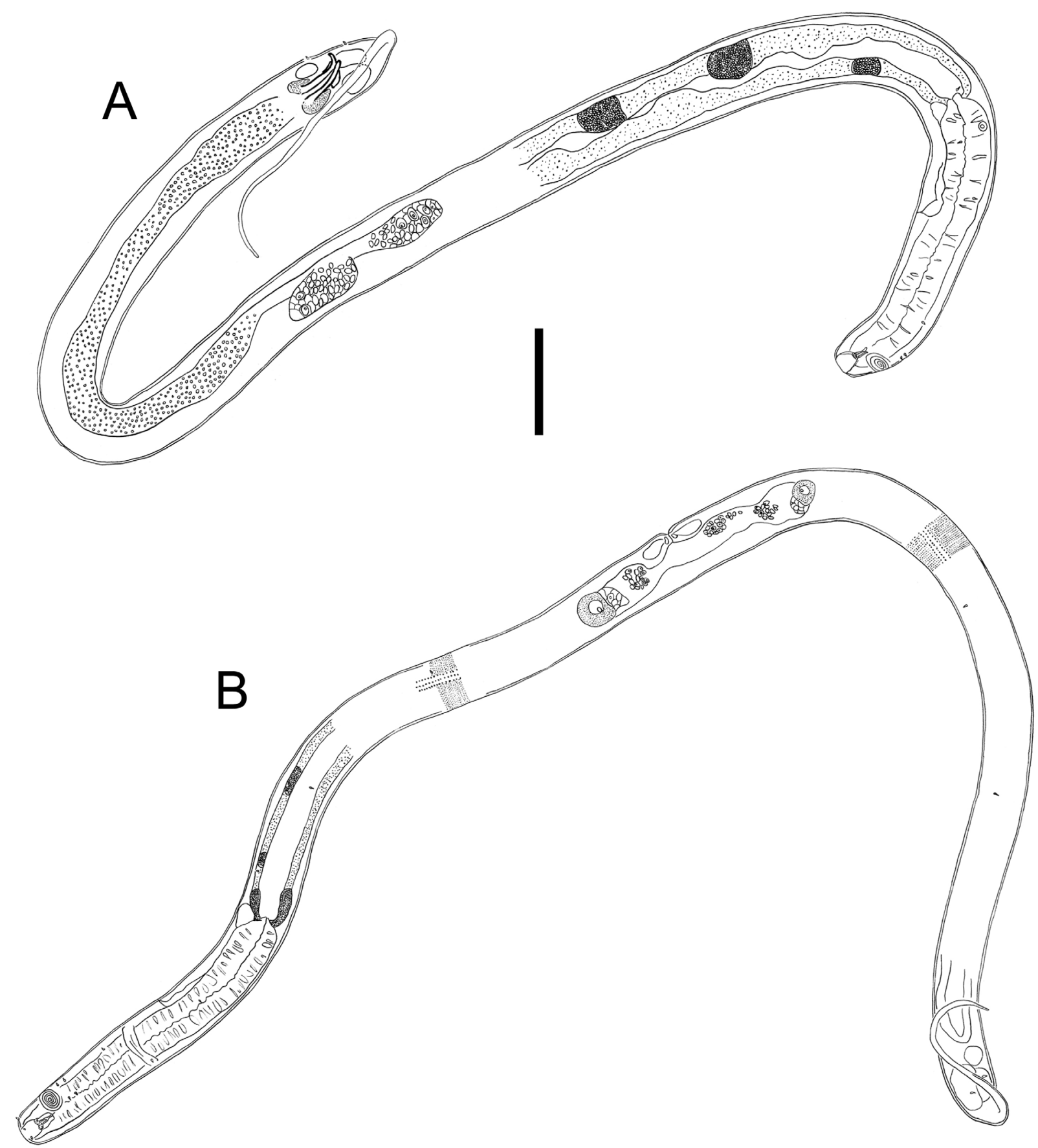

Fig. 15. Bendiella thalassa gen. et sp. nov. A. Entire male. B. Entire female. Scale bar $=50 \mu \mathrm{m}$. 
anterior ends, spicules 1.4 abd, gubernaculum consisting of two detached lateral pieces (crurae) without median portion (corpus or cuneus), and conico-cylindrical tail, 7.0 abd long.

\section{Etymology}

The species name is derived from the Greek word thalassa (= sea).
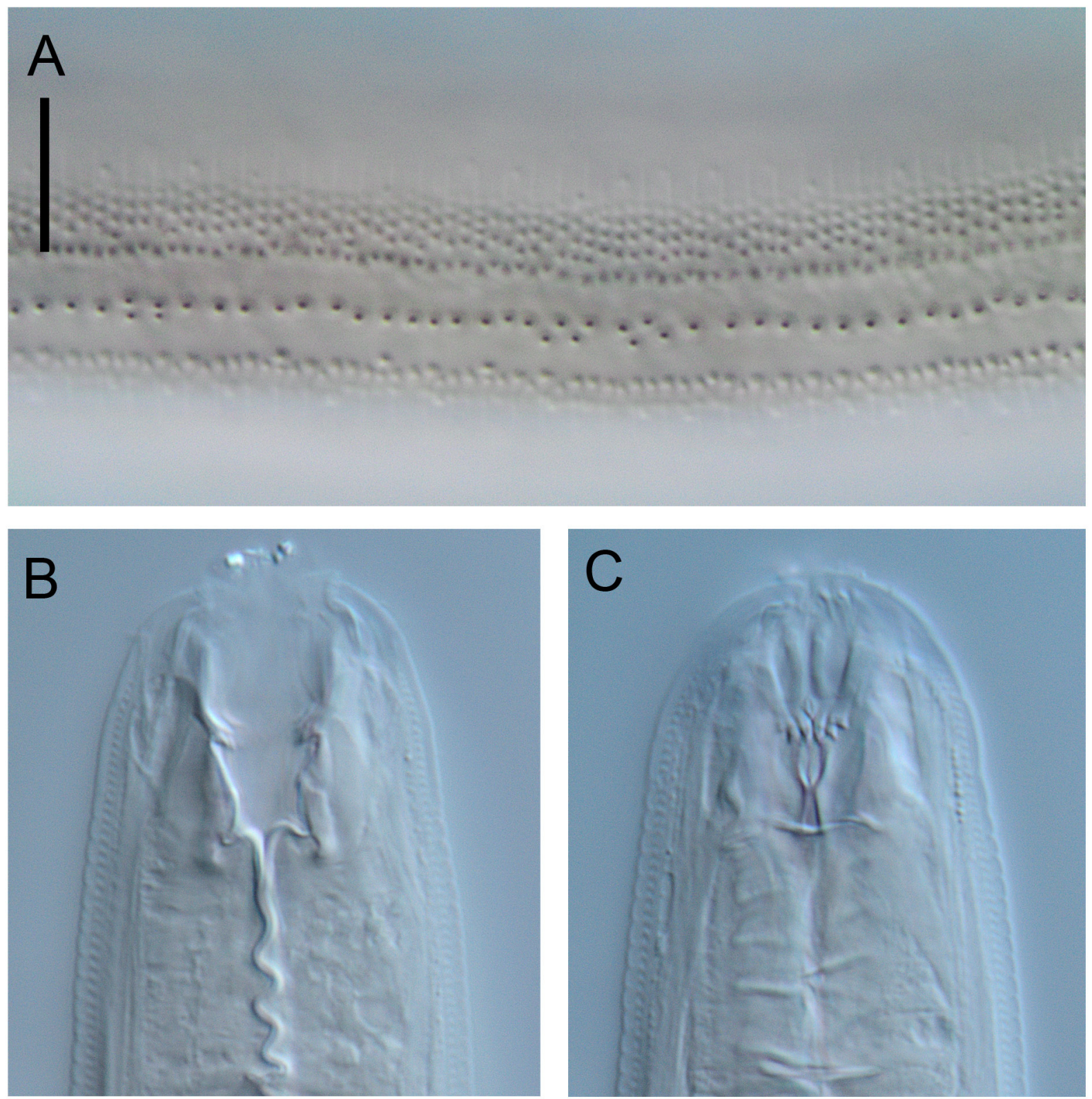

Fig. 16. Bendiella thalassa gen. et sp. nov. Light micrographs. A. Lateral view of male cuticle. B. Female head, showing shape of buccal cavity. C. Female head, showing details of rhabdions in anterior and posterior buccal cavity. Scale bar $=10 \mu \mathrm{m}$. 


\section{Material examined}

Holotype

NEW ZEALAND: ${ }^{1}$, NIWA 88365, 6 Apr. 2007, NIWA cruise TAN0705, station 45, southern flank of Chatham Rise, $44.4864^{\circ} \mathrm{S}, 177.1407^{\circ} \mathrm{E}, 1238 \mathrm{~m}$, silt/clay $(93.9 \%)$.

\section{Paratypes}

NEW ZEALAND: 1 đ, 3 q $q$, NIWA 88366, 4 Jun. 2007, NIWA cruise TAN0707, station 98, eastern Challenger Plateau, $40.1264^{\circ} \mathrm{S}, 170.2217^{\circ} \mathrm{E}, 804 \mathrm{~m}$, silt/clay $(83.3 \%)$, very fine sand $(6.6 \%)$.

\section{Description}

\section{Males}

Body cylindrical, tapering slightly towards anterior extremity. Cuticle $\sim 1.5 \mu \mathrm{m}$ thick, with transverse rows of punctations, lateral differentiation beginning $\sim 1.0 \mathrm{cbd}$ posterior to amphid and ending at level of cloaca, consisting of three longitudinal rows of slightly larger dots (Fig. 16A). Somatic setae short and sparse, irregularly spaced. Head blunt, rounded, not set off. Inner labial papillae minute; six small outer labial setae situated in same circle as four slightly longer cephalic setae, $<0.1 \mathrm{cbd}$. Amphideal fovea multispiral with 5.25 turns, situated $\sim 0.5$ cbd from anterior extremity. Buccal cavity large, divided into anterior and posterior portions. Anterior portion of buccal cavity cylindrical to funnel-shaped, with twelve cuticularised rhabdions, each with one pair of pointed projections at posterior extremity (Fig. 16B, C). Posterior buccal cavity narrower, cylindrical, surrounded by three Y-shaped pairs of slender rhabdions fused from two thirds of distance from anterior ends (Fig. 16C). Pharynx without anterior bulb; pharynx widens posteriorly but not forming true posterior bulb. Nerve ring at $\sim 40 \%$ of pharynx length from anterior. Secretory-excretory (S-E) system present, cellular body of ventral gland small, situated at posterior end of pharynx, pore situated $\sim 0.6 \mathrm{cbd}$ posterior to nerve ring. Intestine cells with numerous round inclusions, some cells differentiated by presence of more numerous and closely packed inclusions (Fig. 15).

Reproductive system diorchic with short, $\sim 40-45 \mu \mathrm{m}$ long, outsretched testes. Anterior testis on right of intestine, posterior testis on left of intestine; small, round sperm cells, $2 \mu \mathrm{m}$ in diameter. Spicules paired, 1.4 abd long, curved, tapering distally. Gubernaculum consisting of two detached lateral pieces (crurae) tapering distally; median portion of gubernaculum (corpus and cuneus) apparently absent. Precloacal supplements and seta absent. Two round hypodermal glands situated laterally at level of cloaca, each connected to short seta. Tail 7.0 abd long, conico-cylindrical, with short, sparse setae and pointed extremity. Three caudal glands and spinneret present.

\section{Females}

Similar to male, but with slightly smaller amphid situated $1.0 \mathrm{cbd}$ from anterior extremity. Reproductive system didelphic-amphidelphic, with reflected ovaries. Anterior ovary on left of intestine, posterior ovary on right of intestine. Vulva located slightly pre-median. Pars proximalis vaginae surrounded by constrictor muscle, vaginal glands not observed. Anus not observed.

\section{Discussion}

The present study brings the total number of deep-sea selachinematid species to thirteen (Miljutin et al. 2010). Of the species described in the present study, Gammanema agglutinans sp. nov. was by far the most common, with records from fourteen sites on Chatham Rise and Challenger Plateau (Fig. 17). Bendiella thalassa gen. et sp. nov. was also recorded from Chatham Rise and Challenger Plateau (three sites), whereas Cobbionema trigamma sp. nov., Pseudocheironchus ingluviosus sp. nov., and Synonchiella rotundicauda sp. nov. were only recorded at Chatham Rise sites. 


\section{Acknowledgements}

This research was funded by NIWA under Coasts and Oceans Research programme 2 (2013/14 SCI). Sample data were generated under the Ocean Survey 20/20 Chatham-Challenger project for which I thank the funding agencies, Land Information New Zealand, Ministry of Fisheries, Department of
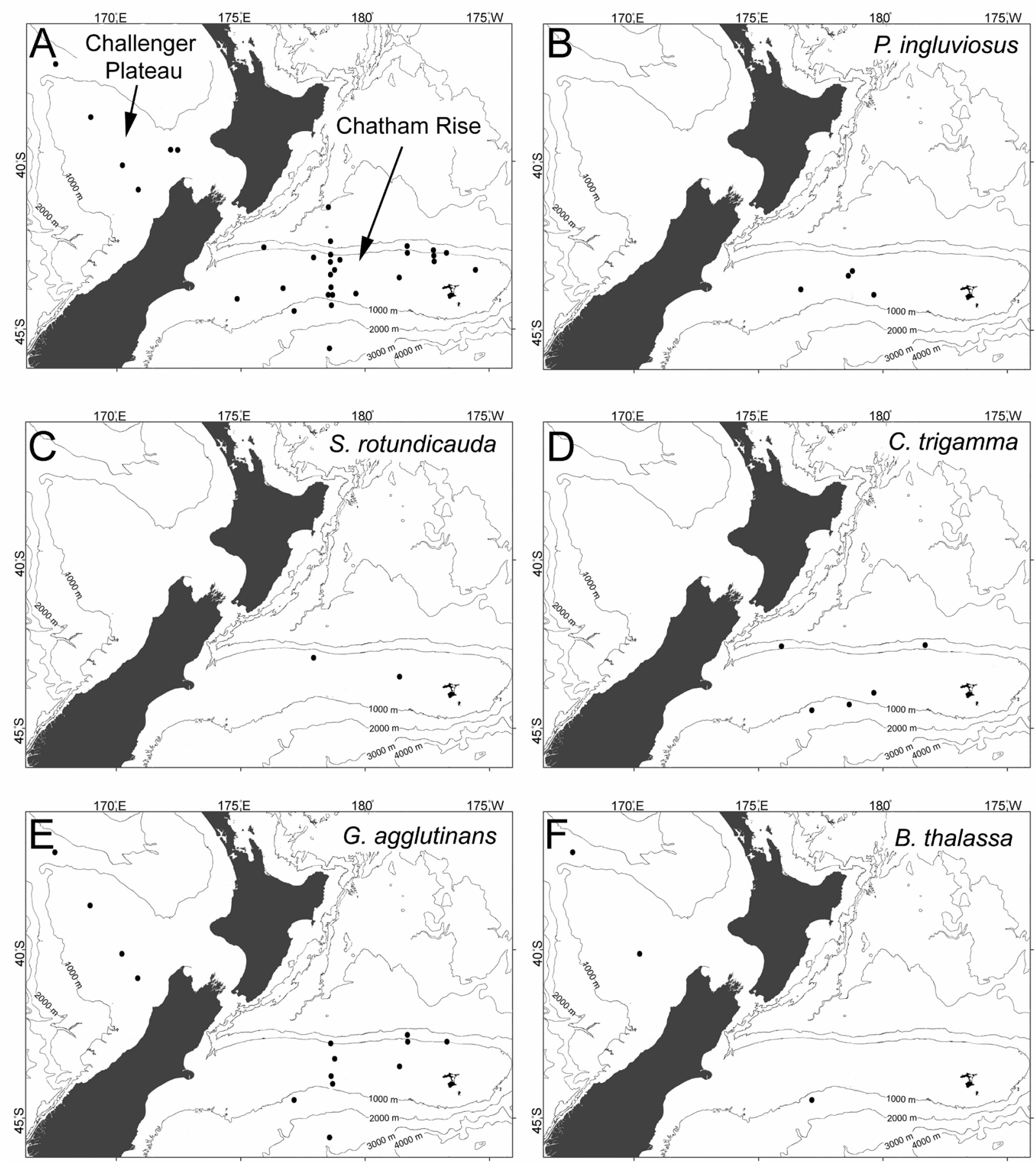

Fig. 17. Map of the New Zealand region with $1000 \mathrm{~m}$ water depth contours. A. Location of the sites sampled on Chatham Rise and Challenger Plateau. - B-F. Distributions of individual species. - B. Pseudocheironchus ingluviosus gen. et sp. nov. C. Synonchiella rotundicauda sp. nov. D. Cobbionema trigamma sp. nov. E. Gammanema agglutinans sp. nov. F. Bendiella thalassa gen. et sp. nov. 
LEDUC D., Selachinematidae from the continental slope of New Zealand

Conservation and NIWA, for permission to use the data and samples. I also acknowledge the other participants of voyages TAN0116, TAN0705, TAN0707, TAN1103, and TAN1116, and the officers and crew of the RV Tangaroa. I am grateful to Natalia Fadeeva and an anonymous reviewer for providing constructive criticisms on an early draft of the manuscript.

\section{References}

Decraemer W. \& Smol N. 2006. Orders Chromadorida, Desmodorida and Desmoscolecida. In: Abebe E.-A., Transpurger W. \& Andrassy I. (eds) Freshwater Nematodes: Ecology and Taxonomy: 497-573. Cambridge, UK, CABI Publishing.

Fadeeva N.P. 1988. On the study of the nematodes of the family Selachinematidae (Chromadorlda, Chonlolaimoidea). Proceedings of the Zoological Institute, Leningrad 180: 33-42 (in Russian).

Filipjev I.N. 1922. New data about free-living nematodes of the Black Sea. Transactions of Stavropol Agricultural Institute 1: 83-184 (in Russian).

Filipjev I.N. 1926. Freilebende marine Nematoden aus der Umgebung von Sebastopol. Travaux du Laboratoire Zoologique et de la Station Biologique de Sébastopol près de l'Académie des Sciences de Russie, Série II (4).

Furstenberg J.P. \& Heyns J. 1987. Cobbionema capense n. sp. from Swartkops estuary, Port Elizabeth (Nematoda: Selachinematidae). Canadian Journal of Zoology 65: 80-82.

Gerlach S.A. 1964. Revision derChoniolaiminae und Selachinematinae (freilebende Meeres-Nematoden). Mitteilungen aus dem Hamburgischen Zoologischen Museum und Institut (Kosswig-Festschrift): 23-49.

Gourbault N. \& Vincx M. 1985. Nématodes abyssaux (campagne Walda du N/O "Jean Charcot"). V. Espèces nouvelles de Selachinematidae, dépourvues d'anus. Cahiers de Biologie Marine 16: 87-97.

Hope W.D. \& Murphy D.G. 1972. Taxonomic hierarchy and checklist of the genera and higher taxa of marine nematodes. Smithsonian Contributions to Zoology 137: 1-101. http://dx.doi.org/10.5479/ si.00810282.137

Jensen P. 1987. Feeding ecology of free-living aquatic nematodes. Marine Ecology Progress Series 35: 187-196. http://dx.doi.org/10.3354/meps035187

Leduc D. \& Gwyther J. 2008. Description of new species of Setosabatieria and Desmolaimus (Nematoda: Monhysterida) and a checklist of New Zealand free-living marine nematode species. New Zealand Journal of Marine and Freshwater Research 42:339-362.http://dx.doi.org/10.1080/00288330809509962

Leduc D., Probert P.K. \& Nodder S.D. 2012a. Two new free-living nematode species (Comesomatidae) from the continental slope of New Zealand, with keys and notes on distribution. Zootaxa 3348: 40-55.

Leduc D., Rowden A.A., Bowden D.A., Nodder S.D., Probert P.K., Pilditch C.A., Duineveld G.C.A. \& Witbaard R. 2012b. Nematode beta diversity on the continental slope of New Zealand: spatial patterns and environmental drivers. Marine Ecology Progress Series 454: 37-52. http://dx.doi.org/10.3354/ meps09690

Lorenzen S. 1981. Entwurf eines phylogenetischen Systems der freilebenden Nematoden. Veröffentlichungen des Instituts für Meeresforschung in Bremerhaven Supplement 7: 1-472.

Miljutin D.M., Gad G., Miljutina M.M., Mokievsky V.O., Fonseca-Genevois V., Esteves A.M. 2010. The state of knowledge on deep-sea nematode taxonomy: how many valid species are known down there? Marine Biodiversity 40: 143-159. http://dx.doi.org/10.1007/s12526-010-0041-4

Neira C. \& Decraemer W. 2009. Desmotersia levinae, a new genus and new species of free-living nematode from bathyal oxygen minimum zone sediments off Callao, Peru, with discussion of the 
classification of the genus Richtersia (Chromadorida: Selachinematidae). Organisms, Diversity \& Evolution 9: 1.e1-1.e15. http://dx.doi.org/10.1016/j.ode.2008.09.004

Okhlopkov J.R. 2002. Free-living nematodes of the families Selachinematidae and Richtersiidae in the White Sea (Nematoda, Chromadorida). Zoosystematica Rossica 11: 41-55.

Pastor de Ward C.T. \& Lo Russo V. 2007. A review of the genus Richtersia (Nematoda: Selachinematidae): new species from Golfo San José and Golfo San Matías, Chubut (Argentina). Journal of the Marine Biological Association of the United Kingdom 87: 1153-1160. http://dx.doi.org/10.1017/ $\underline{\mathrm{S} 0025315407056755}$

Pereira T., Martinez-Arce A., Gingold R. \& Rocha-Olivares A. 2009. Direct nematode predation in the marine nematode Synonchiella spiculora (Selachinematidae: Nematoda). Marine Biodiversity Records 2: e111. 4 pages. http://dx.doi.org/10.1017/S1755267209001092

Schuurmans-Stekhoven J.H. 1950. The freeliving marine nemas of the Mediterranean. I. The Bay of Villefranche. Memoires de l'Institut Royal des Sciences Naturelles de Belgique 37: 1-220.

Somerfield P.J. \& Warwick R.M. 1996. Meiofauna in Marine Pollution Monitoring Programmes: a Laboratory Manual. Ministry of Agriculture, Fisheries and Food, Lowestoft.

Tchesunov A.V. \& Okhlopkov J.R. 2006. On some selachinematid nematodes (Chromadorida: Selachinematidae) deposited in the collection of the Smithsonian National Museum of Natural History. Nematology 8: 21-44. http://dx.doi.org/10.1163/156854106776179890

Warwick R.M. 1971. Nematode associations in the Exe estuary. Journal of the Marine Biological Association of the United Kingdom 51: 439-454. http://dx.doi.org/10.1017/S0025315400031908

Manuscript received: 24 July 2013

Manuscript accepted: 27 September 2013

Published on: 13 November 2013

Topic editor: Rudy Jocqué

Desk editor: Danny Eibye-Jacobsen

Printed versions of all papers are also deposited in the libraries of the institutes that are members of the EJT consortium: Muséum National d'Histoire Naturelle, Paris, France; National Botanic Garden of Belgium, Meise, Belgium; Royal Museum for Central Africa, Tervuren, Belgium; National History Museum, London, United Kingdom; Royal Belgian Institute of Natural Sciences, Brussels, Belgium; Natural History Museum of Denmark, Copenhagen, Denmark. 